\title{
Celebrating 75 years of oestradiol
}

\author{
Evan Simpson ${ }^{1}$ and Richard J Santen ${ }^{2}$ \\ ${ }^{1}$ Hudson Institute of Medical Research, Clayton, Victoria 3168, Australia \\ ${ }^{2}$ Division of Endocrinology and Metabolism, Department of Medicine, University of Virginia Health Sciences System, \\ Charlottesville, Virginia 22908-1416, USA
}

\author{
Correspondence \\ should be addressed \\ to E Simpson \\ Email \\ evan.simpson@ \\ hudson.org.au
}

\begin{abstract}
Oestrogens exert important effects on the reproductive as well as many other organ systems in both men and women. The history of the discovery of oestrogens, the mechanisms of their synthesis, and their therapeutic applications are very important components of the fabric of endocrinology. These aspects provide the rationale for highlighting several key components of this story. Two investigators, Edward Doisy and Alfred Butenandt, purified and crystalized oestrone nearly simultaneously in 1929, and Doisy later discovered oestriol and oestradiol. Butenandt won the Nobel Prize for this work and Doisy's had to await his purification of vitamin K. Early investigators quickly recognized that oestrogens must be synthesized from androgens and later investigators called this process aromatization. The aromatase enzyme was then characterized, its mechanism determined, and its structure identified after successful crystallization. With the development of knock-out methodology, the precise effects of oestrogen in males and females were defined and clinical syndromes of deficiency and excess described. Their discovery ultimately led to the development of oral contraceptives, treatment of menopausal symptoms, therapies for breast cancer, and induction of fertility, among others. The history of the use of oestrogens for postmenopausal women to relieve symptoms has been characterized by cyclic periods of enthusiasm and concern. The individuals involved in these studies, the innovative thinking required, and the detailed understanding made possible by evolving biologic and molecular techniques provide many lessons for current endocrinologists.
\end{abstract}
Key Words
- oestrogen
- oestradiol
- aromatase
- regulation

Journal of Molecular Endocrinology (2015) 55, T1-T20

\section{Discovery of oestrogen}

The concept that substances secreted by one organ could then be transported internally to another via the blood stream is the underpinning of the field of endocrinology. The 'father of physiology', Claude Bernard, articulated the concept of internal secretion by describing how the liver produces glucose, which then travels to and is utilized by other tissues in the body. This concept underlies studies on the ovaries, which became a focus of investigation later in the century. In 1896, Emil Knauer, a 29-year-old Austrian, excised the ovaries of adult rabbits and then re-implanted pieces into different locations in the same animals (Watkins 2007). This prevented uterine atrophy, which would usually be observed following oophorectomy. He postulated that the ovaries must send some type of substance via the blood stream to the uterus. These substances were later called hormones, a term coined by Ernest Starling in 1905 from his studies on secretin. By 1924, much was known about the estrous cycle and its effects on the uterus as detected by careful anatomic and histologic studies in conjunction with the timing of the cycle (Allen 1924).

Science often moves forward under fortuitous circumstances. Two new instructors, Edward Doisy and

Published by Bioscientifica Ltd. 
Edgar Allen, met at the Washington University School of Medicine in 1923. Doisy was a biochemist trained at Harvard by Dr Otto Folin (of the Folin-Wu blood sugar chemical reaction fame), and Edgar Allen, a biologist studying the estrous cycle (Watkins 2007). Both moved to neighboring homes in St Louis and only one, Doisy, could afford a car, a Ford Model T. They shared ideas about their scientific endeavors while they rode to work. Allen was studying the estrous cycle with anatomic and histologic techniques in the mouse and he knew much about the changes that occurred in the uterus. He noted that there appeared to be a relationship between changes in the ovarian follicles and gross and histological changes in the uterus. He too postulated that the ovaries might secrete a hormone. To pursue this idea, he went to the neighboring meatpacking plant and obtained the ovarian follicles of sows. Bringing this material back to the kitchen, he enlisted his wife to help extract the fluid. Thus obtained and injected into immature mice and rats, he observed the stimulation of the uteri. However, he recognized that he had reached an impasse and needed help in purifying the fluid. Doisy, who was busy trying to prepare purified insulin at that time, was convinced to take on this project (Doisy 1976). As the sow ovarian fluid was limited and required tedious isolation methods, Allan and Doisy sought better sources of oestrogen. Doisy came across the work of two German scientists, Selmar Ascheim and Bernard Zondec, who had discovered large amounts of oestrogenic material in the urine of pregnant women. Doisy then enlisted a nurse in the obstetrics clinic to supply each pregnant patient with a 1 gal jug and ask for her urine. This provided the needed material but was fraught with difficulties. Suspected to be a bootlegger because of the large jugs of yellow material in his car, one of Doisy's drivers was nearly arrested until he suggested using the sniff test with the response 'My god, it is urine'. Doisy, then being recruited to St Louis University, continued his efforts to purify the active substance. Each extract was tested with a bioassay and its effect on uterine stimulation. Urine, the material of choice for study, was initially extracted with a very large countercurrent apparatus (Fig. 1). Costing the exorbitant sum of $\$ 750$ (calculated to be $\$ 10000$ in 2015 dollars), Doisy went hat in hand to Dean Hanau Loeb for funding. Having recruited him to St Louis University from Washington University, Loeb reportedly recognized Doisy's brilliance and provided the funds. With this support, Doisy spent the next 5 years developing a multi-step purification procedure. In 1929 he produced pure oestrone crystals (Fig. 2). He then presented his work at the XIII International Physiological
Congress in Boston in September 1929 (Doisy et al. 1929, Veler et al. 1930). Fuller Albright, a rising young endocrinologist, was in the audience and wrote about his reaction to the talk with a verbatim quote in his autobiography (Albright \& Ellsberg 1990): 'a physician rose and quietly stated that he had purified 'folliculin', female sex hormone, to the extent that he had crystals of the material. He showed lantern slides of these crystals. Their potency was so great that one gram could restore the sex cycle in more than nine

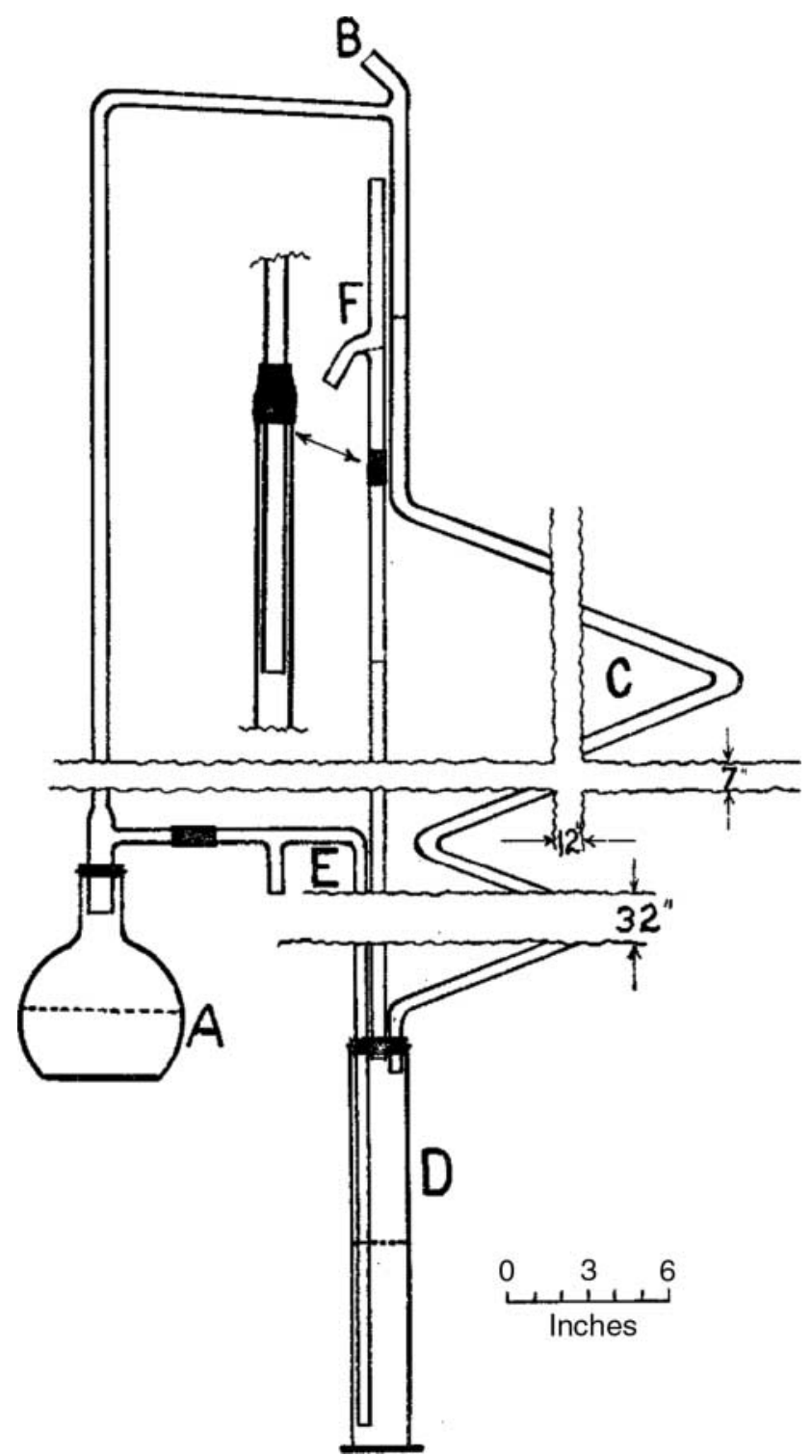

Figure 1

Apparatus designed by Doisy to purify oestrogens from large amounts of urine. Reproduced, with permission, from Veler CD, Thayer S \& Doisy EA (1930) The preparation of the crystalline follicular ovarian hormone: theelin. Journal of Biological Chemistry 87 357-371.

Published by Bioscientifica Ltd. 


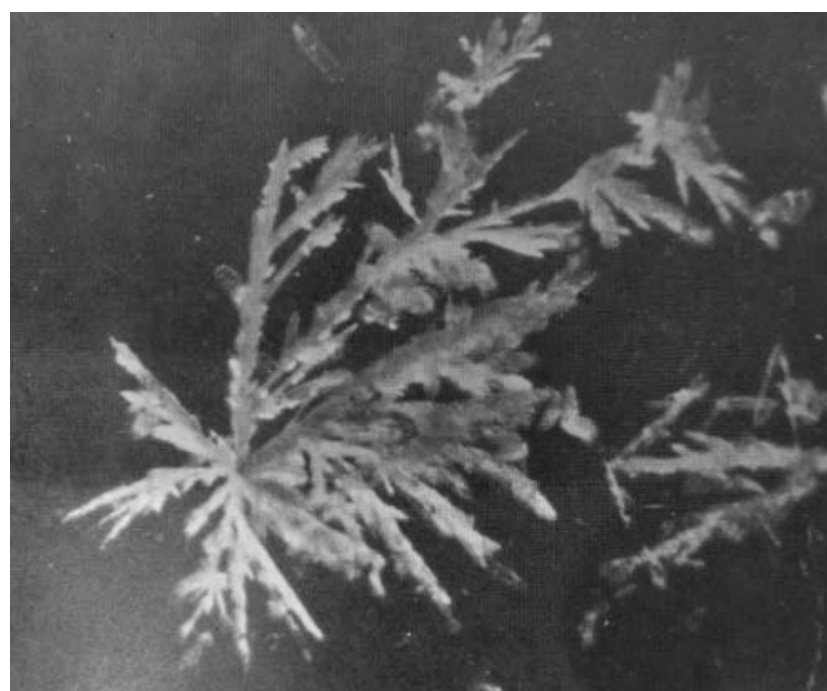

Figure 2

The crystals of theelin published by Doisy after he had purified oestrone from urine (Doisy Museum, St Louis University). Reproduced, with permission, from Veler CD, Thayer S \& Doisy EA (1930) The preparation of the crystalline follicular ovarian hormone: theelin. Journal of Biological Chemistry 87 357-371.

million castrated rats. 'Wanderson' (in German this means fantastic, wonderful, earth shaking) murmured a leading investigator in the field'.

After his discovery, Doisy went home and told his wife that this oestrogenic substance, which he called 'theelin', would make them wealthy. He applied successfully for a patent on oestrogen on 3rd March 1930, and another on 6th October 1930. Both were awarded on 24th July 1934. Remarkably, as Dean Loeb had supported his early work, Doisy assigned the patent to St Louis University. This supported many laboratories and buildings and is now an endowment worth approximately \$150000 000 (US dollars) (Enrico DiCera, personal communication). Continuing his work, Doisy and colleagues later isolated a compound they called dihydrotheelin, which was later named oestradiol (Huffman etal. 1940). Thus, the discovery of oestradiol was made in 1940, exactly 75 years ago.

Surprisingly, Doisy did not win the Nobel Prize for this work as it was awarded in 1939 to Alfred Butenandt, who had purified oestrone at the same time as Doisy and called it progynon (Butenandt 1929). Butenandt later purified testosterone and received his Nobel Prize award in 1939 along with Leopold Ruzincka for the purification of oestrogens and testosterone. For the historical record, Butenandt wrote a published comment of oestrone purification on 14th October 1929, 1 month after Doisy's presentation (Doisy et al. 1929). In German, Butenandt stated, 'The current report about the female sex hormone is being published, because I learned from a participant of the Thirteenth Physiology Congress in Boston [August 1929], that E A Doisy had a short report during that congress that he had been able to crystallize a substance with high efficacy [about 8 million $M E / g r a m]$ from urine of pregnant women. I do not have information about the physical and chemical properties of the Doisy preparation. My own experiments, which were already performed several months ago and which were made possible by the support of the 'Notgemeinschaft der Deutschen Wissenschaften', have resulted in the isolation of a crystallized substance with similar high physiologic efficacy. The chemical analysis of the substance is currently underway'. Butenandt then goes on to describe several steps in purification and then the final step: "with slow sublimation in the high vacuum or by using solvents, a crystallized substance can be separated from this oil which after several crystallization steps still has a high physiologic efficacy of 8 million ME/gram' (Butenandt 1929).

Doisy's first full publication on oestrone was submitted 12th April 1930, and was published later in the year (Veler et al. 1930). How could a discovery be made more simultaneously? Doisy was not to be fully disappointed about the Nobel Prize, however, because he was awarded one in 1943 for the purification of vitamin K. Doisy's continuing work led to a manuscript describing oestriol, which he called theelol (Thayer et al. 1931), in 1931 and oestradiol, which he called dihydrotheelin, in 1940 (Huffman et al. 1940). As later studies on oestrogen progressed in the early 1930s, a controversy arose about the ring structure of the oestrogens, whether it had three rings or four. At an international conference in 1935 you can clearly see Butenandt holding up four fingers indicating that he believed in a four-ring structure (Fig. 3).

The similarity of the structure of testosterone and oestradiol led Zondek to postulate the conversion of androgens to oestrogens (Zondek 1934). Steinach \& Kun then tested the hypothesis that testosterone was a precursor of oestradiol (Steinach \& Kun 1936, 1937). They originally demonstrated this conversion in male rats (Steinach \& Kun 1936) and then a year later in five men (Steinach \& Kun 1937). They injected men with testosterone propionate, $50 \mathrm{mg} /$ injection three times per week with a total of 20 injections, and bioassayed urinary oestrogen before and after. Oestrogen levels were between 0 and 36 rat units before the injections, and after, the maximum measured was 1200 rat units (Steinach \& Kun 1937). They concluded that 'male hormone, when injected, must therefore be transformed in the body into this physiological substance, i.e., urinary oestrogen'. To our knowledge, this

Published by Bioscientifica Ltd. 


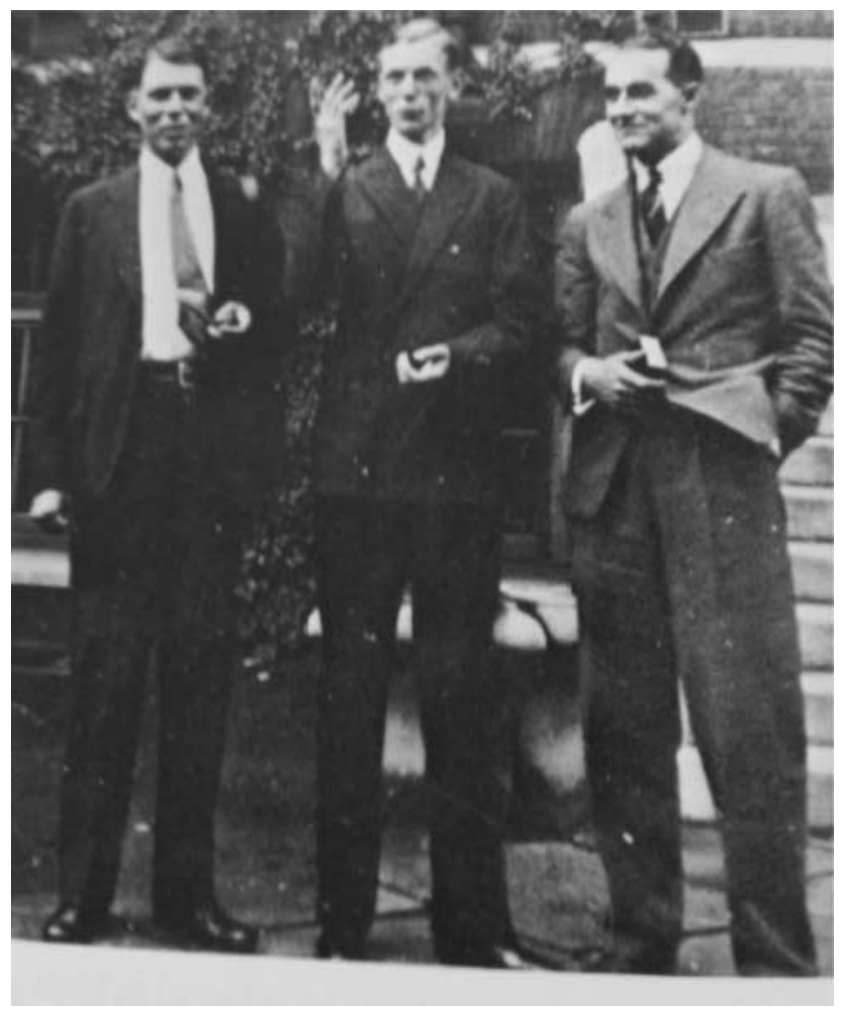

Figure 3

Photograph of Doisy (far left) and Butenandt (middle) and unknown investigator (far right) at an international meeting in 1935. There was a controversy at that time as to whether oestrogen molecules had three or four rings. Note that Butanandt favors the four-ring concept as indicated by his four raised fingers. Reproduced with permission from the Doisy Museum, St Louis University, St Louis, MO, USA.

study provided the initial demonstration of aromatase, first in male rats and then in men.

\section{Biosynthesis of oestrogens: aromatase and its mechanism}

The suggestion that C19 androgens might be directly converted to C18 phenolic oestrogens (Zondek 1934, Steinach \& Kun 1936, 1937) led to the coining of the term aromatase for this reaction (notably, the authors, after exhaustive searching, have not been able to determine who coined the term aromatase). Because of the interest in the development of oral contraceptives, the Worcester Foundation for Experimental Biology in Shrewsbury, Massachusetts, became a major focus for this work. In 1955, Meyer made the crucial discovery that androstenedione was hydroxylated by the bovine adrenal to yield 19-hydroxyandrostenedione (19-OH-A) (Meyer 1955, Meyer et al. 1955). Studies on the aromatase reaction were greatly improved by the development by Ryan and Engel of human placental microsomes as a source of high aromatase activity. Work from the Hayano team led Tomas Morato and colleagues to propose 19-oxo-androstenedione (19-oxo) as the intermediary between 19-OH-A and oestrogen (Morato et al. 1961) and to postulate the sequence to be testosterone $\rightarrow 19-\mathrm{OH}-\mathrm{A} \rightarrow 19$-oxo $\rightarrow$ oestrogen. They also noted the strict requirement of reduced nicotinamide adenine dinucleotide phosphate (NADPH) and oxygen for the conversion of both 19-oxygenated compounds to oestrogens. One question that arose at the time was whether or not a single enzyme was involved in the aromatization reaction or whether separate enzymes catalyzed the different steps.

Definitive proof that only a single enzyme was involved awaited purification of aromatase in the 1980s. Work on the mechanism was continued by a number of investigators including Aubrey Thompson, Pentii Siiteri, Paul MacDonald, Harry Brodie, and Jack Fishman. By the early 1970s, investigators generally agreed on several facts regarding the mechanism of aromatase action. Conversion of androstenedione to oestrogen involved 19-OH and 19-oxo intermediates, but not the 19-oic acid, as precursors. The aromatization of ring $A$ involved the

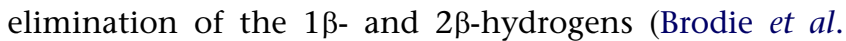
1962, Townsley \& Brodie 1968, Brodie et al. 1969) suggesting that aromatase acted on the $\beta$-face of the substrate. Three moles each of oxygen and reduced NADPH were consumed per mole of androgens converted to oestrogens by the human placental aromatase (Thompson \& Siiteri 1974, 1979). The reaction involved a cytochrome P450-mediated enzyme, as evidenced by blockade with aminoglutethimide (AG), a known inhibitor of adrenal P450-mediated hydroxylation (Bolton \& Siiteri 1969, Chakraborty et al. 1972). C Robinson, M Akhtar, D Covery, E Caspi, and others proposed several mechanisms, but details of the reaction sequence, and in particular the third step, continued to elude investigators (Graham-Lorence et al. 1995, Hong et al. 2007).

However, recent studies from Guengerich's group have thrown light on this issue, as shown in Fig. 4 (Yoshimoto \& Guengerich 2014). As indicated above, steps 1 and 2 are generally agreed to involve sequential hydroxylations on the C19 methyl group. This involves the $\mathrm{P}_{450} \mathrm{FeO}^{3+}$ entity and hydrogen atom abstraction. Two possibilities are shown for step 3 in the presence of ${ }^{18} \mathrm{O}$. In step $3(\mathrm{a})$, the $\mathrm{FeO}^{-}$entity participates in a nucleophilic attack on the 19-aldehyde III-oxo. In step 3(b), the $\mathrm{FeO}^{3+}$ form of the $\mathrm{P} 450$ abstracts the $1 \beta$-hydrogen atom of III-g. Electron transfer results in the collapse of this

Published by Bioscientifica Ltd 

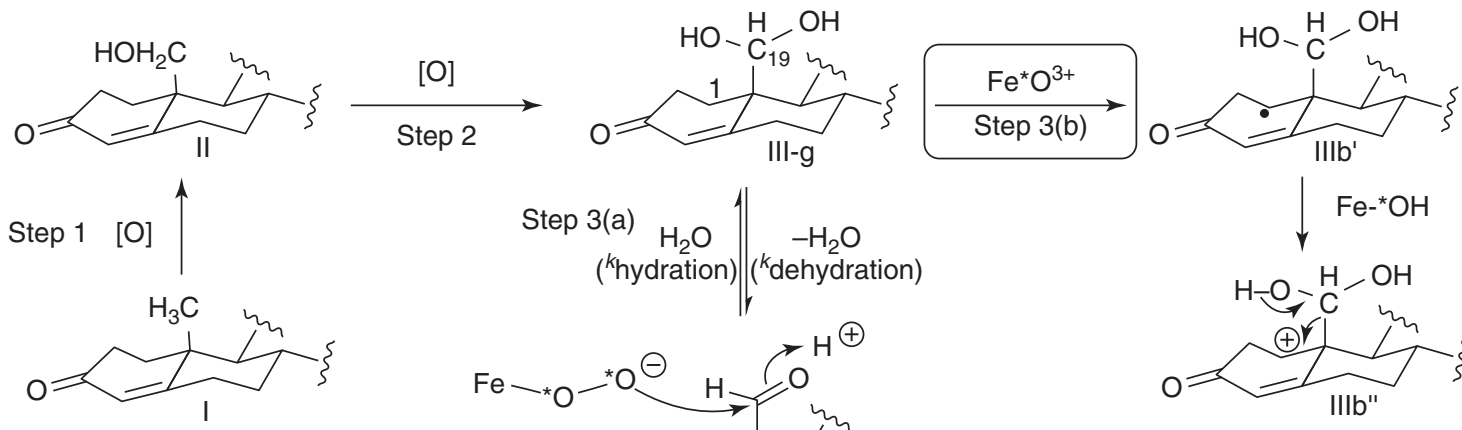

Step 3(a) $\mathrm{H}_{2} \mathrm{O} \quad 1 \quad-\mathrm{H}_{2} \mathrm{O}$

('hydration) ('kdehydration)

$\mathrm{Fe}-{ }^{\star} \mathrm{OH}$
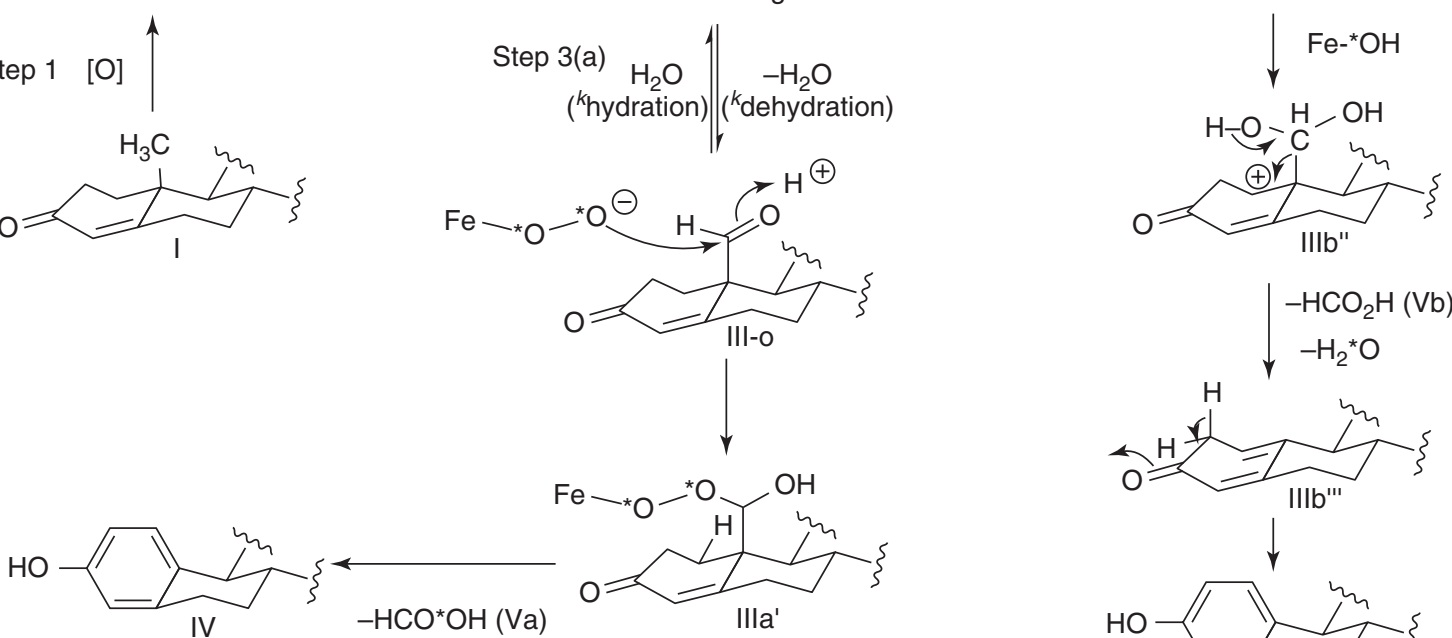

\section{Figure 4}

Reaction sequence of aromatase showing detail of two possibilities for the proposed third step. The data support step 3(b). For details, see section 'Biosynthesis of oestrogens: aromatase and its mechanism'. Data from Yoshimoto \& Guengerich (2014).

intermediate to yield the oestrogen product IV. In step $3(\mathrm{a})$, the formic acid must contain label $\left({ }^{18} \mathrm{O}\right)$, but not in step 3(b). This study supports the mechanism shown in step 3(b).

\section{Biosynthesis of oestrogens: purification, structural characterization, and regulation of aromatase}

\section{Purification}

In the 1980s, Y Osawa, P Hall, L Vickery, F Bellino, N Muto, M Pasonen, O Pelkonen, E Simpson, and C Mendelson purified the human aromatase cytochrome $\mathrm{P} 450$ protein from human placental microsomes and demonstrated conversion of androstenedione to oestrone with purified enzyme (Pasanen \& Pelkonen 1981, Mendelson et al. 1985, Muto \& Tan 1985, Hall et al. 1987, Kellis \& Vickery 1987, Osawa et al. 1987). These studies provided definitive evidence that aromatization involved a single enzyme, and not multiple enzymes as originally thought.

This work allowed the generation of polyclonal antibody and $\mathrm{MAB}$, and with advances in recombinant DNA technology, several laboratories isolated cDNA clones complementary to aromatase transcripts. The group of Simpson and Mendelson screened a $\lambda$ gt11 phage human expression library with antibodies raised against the human aromatase protein (Evans et al. 1986) to isolate a partial cDNA clone lacking the $5^{\prime}$-end but containing the heme-binding region. Use of $5^{\prime}$-RACE led to the characterization of the sequence of the $5^{\prime}$-end of the cDNA, thus yielding the entire cDNA and amino acid sequence of the human aromatase protein, with a total of 503 amino acids and a molecular weight of $58 \mathrm{kDa}$. Subsequently, similar techniques identified aromatase sequences from numerous species (Corbin et al. 1988, Harada 1988, McPhaul et al. 1988, Toda et al. 1989, Hickey et al. 1990, Terashima et al. 1991, Tanaka et al. 1992).

\section{Three-dimensional structure}

Studies of aromatase structure were initially hampered by the fact that it was membrane bound, its expression levels were low, and the heme configuration was readily lost during purification. For this reason, a number of groups sought to model the three-dimensional (3D) structure of the aromatase protein based on the known structures of other cytochrome P450 species. The structures known at the time were those of soluble prokaryotic cytochrome P450 species, and early modeling attempts were based on these structures, which, however, had low sequence homology to aromatase (Laughton et al. 1993,

Published by Bioscientifica Ltd 
Graham-Lorence et al. 1995, Koymans et al. 1995, Williams et al. 2000). Structures of several mammalian microsomal P450 species have been characterized subsequently (Williams et al. 2000) and models of aromatase have been built from them (Favia et al. 2006). Additionally, epitope characterization using monoclonal antibodies has added to our understanding of aromatase-reductase interactions (Hong et al. 2009). More recently, the group of Debashis Ghosh in Buffalo, New York, characterized the actual 3D crystal structure of human aromatase (Ghosh et al. 2009, Hong et al. 2010; Fig. 5). His group achieved this by using aromatase purified from placental microsomes as the source material rather than recombinant protein with a modified N-terminal - an achievement requiring more than a decade of improvements in the biochemical purification techniques originated by Yoshio Osawa. Subsequently, this group also published the 3D structure of a recombinant human aromatase protein, which confirmed the group's original structure.

\section{Characterization of the human aromatase gene}

Screening of human genomic libraries followed identification of aromatase cDNAs, and the groups of Simpson,
Harada, and Toda independently characterized the exonic sequences of the human aromatase gene (Means et al. 1989, Harada et al. 1990, Toda et al. 1990). The nine coding exons included exons II-X, with the heme-binding region residing in exon $\mathrm{X}$, and were $\sim 30 \mathrm{~kb}$ in length in total. The findings regarding exon I turned out to be, for the time, quite novel and very important. The $5^{\prime}$-ends of the transcripts from different tissues revealed divergent sequences upstream of the start of translation such that placenta, ovary, and adipose tissue each exhibited unique exons I (Mahendroo et al. 1991, Means et al. 1991, Toda \& Shizuta 1993). These unique first exons were spliced into a common $3^{\prime}$ junction upstream of the start of translation in a tissue-specific fashion such that the protein synthesized in each case was identical (Fig. 6). However, there was a missing sequence between the most distant placental promoter, the intermediate adipose promoter, and the proximal ovarian promoter, which remained unidentified until the human genome sequence data became available. At that time, the gap was finally closed by Bulun and colleagues (Bulun et al. 2004). The complete structure of the human aromatase gene encompasses a span of about $123 \mathrm{~kb}$. The human gene is assigned as CYP19A1, and the mouse gene as cyp19A1.

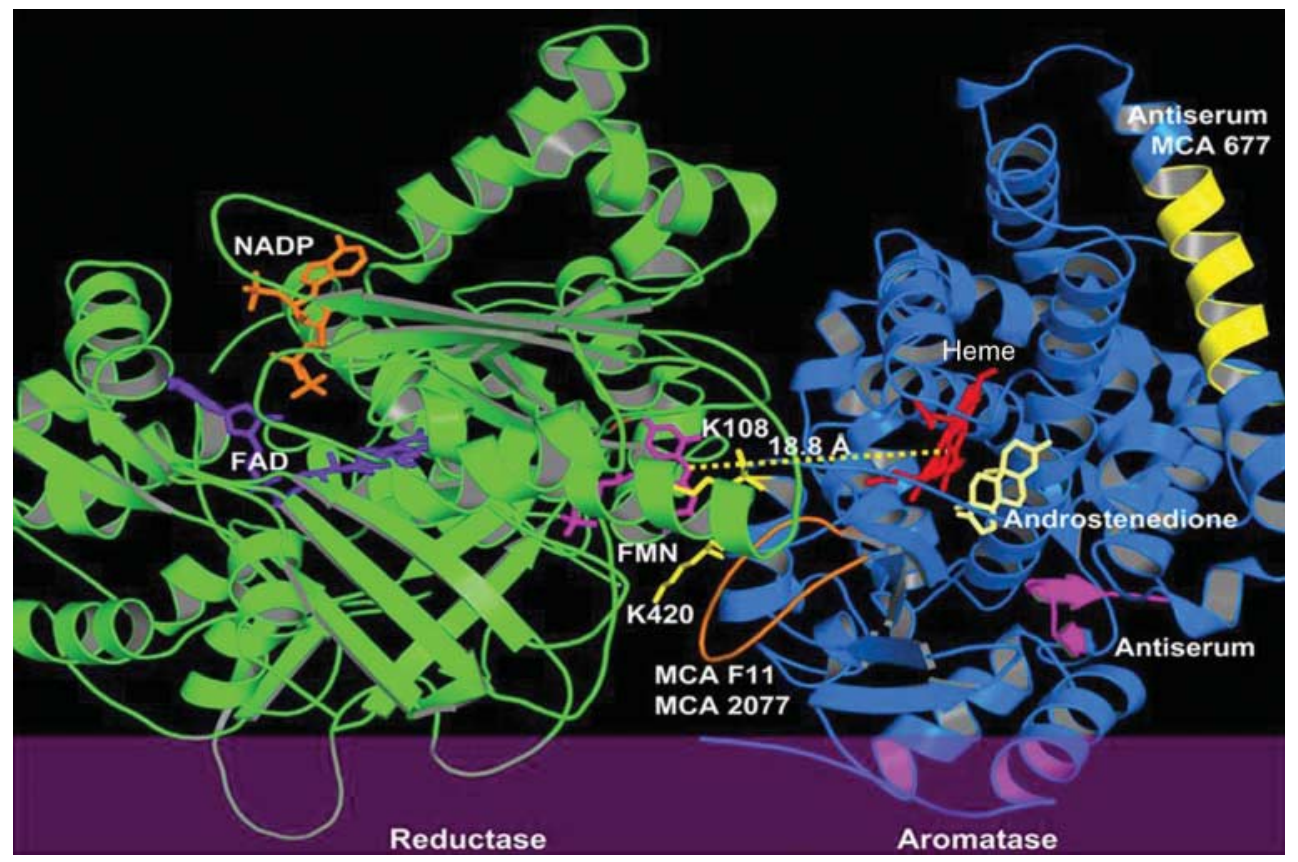

Figure 5

Crystal structure of aromatase shown complexed with NADPH reductase in a docking model. Reproduced, with permission, under the terms of the CCBY license from Hong Y, Li H, Ye J, Miki Y, Yuan YC, Sasano H, Evans DB \&
Chen S (2009) Epitope characterization of an aromatase monoclonal antibody suitable for the assessment of intratumoral aromatase activity. PLOS ONE 4 e8050.

Published by Bioscientifica Ltd. 


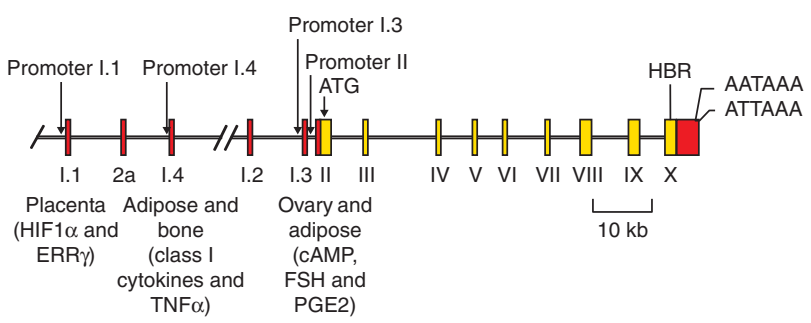

Figure 6

Diagram of the aromatase gene showing the coding region comprising exons II-X and the tissue-specific distribution of the various untranslated first exons. For further details, see section 'Biosynthesis of oestrogens: purification, structural characterization, and regulation of aromatase'.

\section{Promoter regulation}

The discovery of tissue-specific first exons in the aromatase gene led to the realization that tissue-specific promoters were located upstream of each of these first exons (Fig. 6). It followed that these promoter regions were regulatory sites for tissue-specific transacting elements. Thus, for example, upstream of the placenta-specific first exon is a promoter region (promoter I.1), which is regulated by HIF $1 \alpha$ and ERR $\gamma$. This first exon is located some $90 \mathrm{~kb}$ upstream of the translational start site, which implies that the entire sequence in between is spliced out during processing of the placental aromatase transcript. On the other hand, the ovarian first exon is proximal to the translational start site and its promoter contains two CREs and, hence, is regulated by cAMP. Thus, in the ovary this promoter (promoter II) is regulated by the folliclestimulating hormone. Aromatase expression in adipose tissue occurs not in the lipid-laden adipocytes, but rather in the stromal elements - the mesenchymal cells that surround the adipocytes. In these cells, it is regulated primarily by another distal promoter (promoter I.4), which is regulated by class 1 cytokines such as interleukin 6 and also by tumor necrosis factor alpha. However, transcripts from the ovarian promoter II are also present in adipose stromal cells and these become dominant in cancer-associated fibroblasts surrounding a breast tumor, as will be discussed below. In this case however, the promoter and, hence, the aromatase gene are regulated by prostaglandin E2 (PGE2).

\section{Molecular mechanisms of action of oestrogens}

Oestradiol exerts its effects after binding to oestrogen receptors alpha $(\mathrm{ER} \alpha$ ) and $\operatorname{ER} \beta$ (Kim \& Levin 2006, Madak-Erdogan et al. 2008, Levin 2009, 2014b, 2015,
Welboren et al. 2009, Chambliss et al. 2010, SchultzNorton et al. 2011, Filardo \& Thomas 2012, Arnal et al. 2013, Hamilton et al. 2014, Magnani \& Lupien 2014). The predominant actions are mediated through the direct binding of the receptor to oestrogen response elements (EREs) in the nucleus and the initiation of transcription or by tethering to other transcription factors, such as AP1 and SP1, with DNA binding to their respective response elements. For specific details of nuclear effects, see references above. Emerging data have described membrane initiated oestrogen effects that deserve greater emphasis because of the more recent understanding of these actions, which are detailed below.

\section{Membrane initiated oestrogen effects}

Introduction Classical concepts held that $\mathrm{ER} \alpha$ and $\mathrm{ER} \beta$ require translocation into the nucleus to exert their actions by binding to EREs on DNA or through tethering to AP1 or other proteins. Studies over the past decade have clearly demonstrated a role for ERs residing near or in the plasma membrane and a role for ER in the mitochondria (Pietras \& Szego 1977, Selvaraj et al. 2000, Watters et al. 2000, Song et al. 2004, 2007, Yang et al. 2004, Dahlman-Wright et al. 2006, Song 2007, Yager \& Chen 2007, Madak-Erdogan et al. 2008, Haas et al. 2009, Pedram et al. 2009, Li et al. 2010, Flamini et al. 2011, Sanchez et al. 2011, Wu et al. 2011, Razandi et al. 2013, Levin 2014a,b, 2015, Marjon et al. 2014). Cytosolic ER is palmitoylated, which allows localization in or near the plasma membrane. Portions of the membrane containing caveolin contain the highest concentrations of receptor. Signaling from the membrane ER is complex and involves several pathways depending on the tissue involved. These include rapid activation of at least seven different components: insulin-like growth factor 1 (IGF1) receptor, epidermal growth factor (EGF) receptor, p21 and Raf, MAP kinase (MAPK) and AKT, protein kinase $\mathrm{C}$, release of nitric oxide and stimulation of prolactin secretin, and alteration of calcium and Maxi-K channels (Song et al. 2007). Although membrane-initiated effects of the ER were originally described by Szego \& Pietras three decades ago (Pietras \& Szego 1977), their presence and importance remained controversial until recently. A key observation that began to gain acceptance regarding extra-nuclear actions was the very rapid (i.e. within $5 \mathrm{~min}$ ) activation of MAPK (Song et al. 2004, Song 2007, Madak-Erdogan et al. 2008). Use of oestradiol-linked dendrimer conjugates (EDCs), which could not enter the nucleus, provided additional credibility (Harrington et al. 2006). Finally, the

Published by Bioscientifica Ltd. 
demonstration that MAPK could bind to ER $\alpha$, stimulate a unique set of genes, and be captured on DNA via chip assays in conjunction with ER $\alpha$ provided compelling evidence of the functionality of membrane-initiated events (Madak-Erdogan et al. 2008). The signaling pathways that transduce the rapid effects of oestradiol are complex and differ according to cell type.

\section{Breast cancer cells}

MAPK and transcriptional events in the nucleus Membrane-initiated effects result in the activation of MAPK with a peak at $15 \mathrm{~min}$ and effects lasting for at least $45 \mathrm{~min}$ in breast cancer cells. Under oestrogen stimulation, ER $\alpha$ binds directly with MAPK (Madak-Erdogan et al. 2008), the ERK1 and ERK2 subcomponents, and this complex enters the nucleus and binds to ERE sites on chromatin. Directed to the ERE sites on DNA, the ER $\alpha$-MAPK complexes stimulate proliferation. Blockade of MAPK activity with a MAPK inhibitor completely blocks the effect of oestrogen to stimulate proliferation. Two-thirds of the MAPK molecules are bound to ERE elements on DNA, whereas one-third binds directly to MAPK responsive elements. The MAPK molecules are tethered to ERs, which in turn bind to EREs in DNA. Other MAPK molecules are not bound to ER $\alpha$ and form contacts with their own response elements. The ER $\alpha$-MAPK sites are thought to be the most important biologically (Madak-Erdogan et al. 2008). Once MAPK tethered to ER $\alpha$ reaches the ERE sites on DNA, MAPK can phosphorylate several co-activators including SRC3, RIP 140, p300, ad CREB 1. The ER $\alpha$-MAPK sites are in distal enhancer regions, whereas the MAPK-only sites are more proximal in promoter regions. It is of interest that the rapid actions of oestradiol activate MAPK in the region of the cell membrane. The later effects of MAPK, however, occur at the nuclear level. There, the MAPK and ER pathways converge with co-localization in the nucleus. This allows the kinase component to phosphorylate and activate the protein co-activators.

Linear process involving IGF1 and EGF It is known that in noncancer cells IGF1 initiates a linear process involving the activation of the IGF1 receptor and matrix metaloproteinases (MMPs), release of heparin-binding EGF (HBEGF), and activation of the EGF receptor-dependent MAPK. This linear pathway is utilized by several other hormonal systems to stimulate proliferation. These include pathways involving $\mathrm{GH}$, prolactin, integrin, and $\mathrm{G}$ protein coupled receptors such as receptors for endothelin, lysophosphatidic acid, angiotensin, and thrombin. In MCF7 cells, oestradiol induces a similar linear pathway with sequential activation of the IGFR, MMP, EGFR, and MAPK (Song et al. 2004). The HBEGF is involved as shown by neutralizing antibody studies. A variety of docking proteins such as $\mathrm{SHC}$, insulin receptor substrate 1 , and the 85 alpha subunit of phosphoinositide-3-kinase that contains SRC homology 2 domains are also involved. In this pathway, MAPK activates cSRC, which in turn binds to IGF1 receptor and activates downstream IGF1 effects. These actions, in conjunction with the nuclear actions of MAPK tethered to the ER, regulate oestradiolinduced cell proliferation. Thus, a blockade of MAPK completely inhibits oestradiol stimulation of proliferation in breast cancer cells.

Cell migration The rapid effects of oestradiol also cause morphologic changes in the cell membrane with formation of ruffles and pseudopodia and translocation of ER $\alpha$ to the plasma membrane (Song et al. 2004). These effects require activation of SRC and participation of SHC. Cell migration and invasion are stimulated in ER-positive breast cancer cells via similar mechanisms. Oestradiol through the activation of MAPK phosphorylates cSRC, which then interacts with the delta 5 truncated form of SRC3 and focal adhesion kinase to stimulate cell migration and invasion. As a reflection of this process, the leading edges of breast cancer cells change their appearance and filopodia and pseudopodia develop. This can occur as early as $10 \mathrm{~min}$ after exposure to oestrogen (Li et al. 2010, Flamini et al. 2011, Sanchez et al. 2011).

Liver cells Membrane ER stimulates a myriad of genes involved in lipid synthesis and metabolism in the liver. Proof of these effects devolved from the membrane-only ER (MOER) mouse model (Pedram et al. 2009, Levin $2014 a$ ). This model involves the initial creation of $\mathrm{ER} \alpha$ and $\mathrm{ER} \beta$ knock-out $(\mathrm{KO})$ mice in which the E region of the ER is transfected. This MOER construct locks ER $\alpha$ and ER $\beta$, and thus the oestrogen effects in this model cannot reflect transcriptional events. The E region contains the ligandbinding domain but not the nuclear localization signal or activation function 1 transactivational properties. A series of unique genes are indirectly activated in the livers of the MOER mice. In this system, the oestradiol/ER complex activates a pertussis toxin inhibited $G$ coupled protein. The activation of membrane initiated events in the liver suppresses the levels of lipid synthesis-related genes and decreases the levels of cholesterol, triglyceride, and fatty acid content of the liver. A major modulator is the activation of AMP kinase and its downstream effects

Published by Bioscientifica Ltd. 
resulting in the phosphorylation of the sterol regulatory element-binding factor 1.

Vascular endothelial cells In vascular endothelial cells, the ER/oestradiol complex activates a Gai coupled protein complex to activate nitric oxide synthase and to enhance cell proliferation (Chambliss et al. 2010, Wu et al. 2011). These studies utilized the oestradiol-dendrimer complex both invitro and invivo to demonstrate the membrane-initiated effects as opposed to those initiated at the nuclear level. In mice, oestradiol and the oestradiolEDC equally stimulated carotid artery re-endothelialization in an $\mathrm{ER} \alpha$ and $\mathrm{G}$ protein coupled manner, and both agents attenuated the development of neointimal hyperplasia following endothelial injury.

Other tissues oestradiol rapidly stimulates the secretion of prolactin in isolated pituitary cells (Watters et al. 2000). Femoral artery vasodilatation occurs within $3 \mathrm{~min}$, and this can be blocked by inhibitors of MAPK and nitric oxide synthesis.

Mitochondria The simultaneous finding of $\mathrm{ER} \alpha$ and ER $\beta$ in mitochondria independently by Yang et al. (2004) and Yager \& Chen (2007) raised the question of whether oestradiol exerts actions on the mitochondria via ER $\alpha$. Levin (2015) and others provided evidence that several mitochondrial processes could be modulated by this pathway. Several investigators have suggested that mitochondrial ER $\beta$ can enhance cell survival. A recent study suggests that tamoxifen influences the process of apoptosis through interactions with ER $\beta$ in breast cancer cells (Razandi et al. 2013). Tamoxifen, acting either as an antagonist or agonist, differentially regulates manganese superoxide dismutase that impacts reactive oxygen species levels. These effects are thought to occur through the mediation of mitochondrial ER $\beta$.

G protein coupled ER The $G$ protein coupled ER (GPER; formerly known as GP30) is a novel ER with multiple functions in diverse tissues (Marjon et al. 2014). It responds to oestradiol in tissues not containing $\mathrm{ER} \alpha$ or ER $\beta$. Similar to the effects occurring in the ER-mediated linear pathway, GPER stimulates the release of membranetethered HBEGF and activates MAPK and PI3 kinase cascades. GPER has been linked to rapid oestrogen effects on the central nervous, immune, renal, reproductive, and cardiovascular systems (Filardo \& Thomas 2012). Recent studies with $\mathrm{KO}$ mice have suggested a role in mammary tumorigenesis and metastasis (Marjon et al. 2014).
Although originally somewhat controversial, a wide variety of studies in various cells, or organs and species, has provided substantial support for its various roles (Filardo \& Thomas 2012).

\section{Role of local oestrogen synthesis in tissue}

With the realization that the only biosynthetic route to oestrogen was via androgens, it became apparent that women must synthesize androgens and, conversely, men should likely synthesize oestrogens. However, it was generally assumed that the rate of oestrogen synthesis in men was small. More recently, it has become apparent that this is not the case; in fact, men synthesize quantities of oestrogen that can approach those found in women. But the difference is that most oestrogen synthesized in premenopausal women is secreted into the circulation by the ovaries and acts as an endocrine factor, whereas in men the bulk is synthesized in extra-gonadal sites such as adipose tissue and acts locally at these sites in an intracrine (Labrie 2015), autocrine, or paracrine fashion. Thus, circulating levels of oestrogen in men are less important than oestrogens synthesized and acting locally and largely not transported into the blood stream. The prime role for local synthesis is important not only for men but also for postmenopausal women, because the ovaries cease to synthesize oestrogens at the time of menopause.

\section{Disorders characterized by oestrogen insufficiency}

The sexual and bone phenotypes have been reviewed recently (Bulun 2014), so in the interest of space, the results will only be summarized here.

\section{Defects in sexual development}

Girls lacking aromatase, and thus are oestrogen deficient, are typically detected at birth due to virilization of the external genitalia with cliteromegaly. Under these circumstances, androgens cannot be converted to oestrogens and they accumulate to cause virilization. Subsequent development is uneventful until the time of adolescence when the girls fail to go through puberty, are amenorrheic, and lack breast development. They do, however, have pubic hair due to the presence of androgens. They are subsequently given oestrogen replacement to induce sexual maturation.

Female mice lacking aromatase or that are insensitive to oestrogen due to the lack of the ER $\alpha$ receptor develop

Published by Bioscientifica Ltd. 
cystic hemorrhagic follicles and fail to ovulate. Moreover, the granulosa cells take on the appearance of Sertoli cells with tripartite nuclei, cytoplasmic fingers, expression of espin, and sox9. This is an interesting example of trans-differentiation driven by oestrogen, which previously was only recognized in lower vertebrates.

Men with aromatase deficiency typically have low libido and infertility. Recent studies have demonstrated a causal role for oestrogen in the maintenance of libido (Finkelstein et al. 2013). Accordingly, men with aromatase deficiency may have improved libido upon treatment with oestrogen. They also have an impairment of testicular development with variable degrees of phenotypic features, thus, testicular size can vary from 8 to $30 \mathrm{ml}$ and there is also a variable degree of cryptorchidism. Sperm volume and motility are generally compromised, and where a testicular biopsy has been obtained, the seminiferous tubules were dysmorphic.

Male mice with aromatase deficiency also exhibit many of these features, notably loss of libido and the seminiferous tubules that show arrest of germ cell development and lack of sperm (Robertson et al. 1999). Interestingly, this phenotype differs from that of the ER $\alpha$ KO mice, which have grossly distended tubules due to the back up of fluid from the efferent ducts (Couse et al. 1997).

\section{Defects in bone metabolism}

Historically, it was assumed that bone growth and function were regulated by oestrogen in women and by androgens in men. However, studies of normal men, those with aromatase deficiency and one individual with a mutation in the $\mathrm{ER} \alpha$, overturned this concept and led to the conclusion that oestrogen were equally important in the bone physiology of both males and females. Typically, men with aromatase deficiency present with failure of epiphyseal fusion and continued linear growth into their mid-1920s, as well as delayed bone age (Maffei et al. 2004). Oestrogen replacement, but not androgen administration, resulted in epiphyseal closure and improvement in bone age. A characteristic feature of the phenotype of these men is genuvalgum or 'knock-knee'. This is presumably because of the pressure of body weight on undermineralized bones. The man with the ER $\alpha$ mutation had a similar bone phenotype, but this of course could not be reversed. Aromatase is expressed in several cells in bone including osteoblasts, osteocytes, and some osteoclasts so circulating androgens can provide a ready substrate for these cells to convert androgens to oestrogens.

\section{Development of a metabolic syndrome}

Mice of both sexes with an aromatase or ER $\alpha$ KO develop a metabolic syndrome including truncal obesity, hyperinsulinemia, and hyperleptinemia. Male mice with aromatase deficiency also develop hepatic steatosis due to triglyceride accumulation.

These findings are reversed by oestrogen administration in the case of the aromatase deficient mice. In the case of humans, no studies in women with untreated aromatase deficiency have been published; however, the condition in men is well documented. These men develop a full-blown metabolic syndrome with insulin insensitivity; elevated glucose, LDL, and triglycerides; marked hepatic steatosis; and elevated blood amino acids. Treatment with oestradiol for 1 year led to a marked reversal of all of these parameters (Maffei et al. 2004).

A number of other phenotypes of oestrogen deficiency have been described including cognitive defects. These have been documented in postmenopausal women with early-stage breast cancer treated with chemotherapy and an aromatase inhibitor, who exhibited poorer executive function including working memory and concentration (Bender et al. 2015).

\section{Phenotypes of oestrogen excess}

In humans, endogenous oestrogen excess can arise from three sources - either naturally-occurring gain of function mutations in the promoter region of the aromatase gene resulting in elevated expression of the gene, the PeutzJeghers syndrome, or an ectopic source of oestrogen such as a tumor. Aromatase excess syndrome results from subchromosomal recombination events including duplication, deletion, and inversion (Shozu \& Simpson 1998, Shozu et al. 2002). The latter two recombinations result in recruitment of novel promoters for CYP19A1. Serum oestradiol levels are elevated in $48 \%$ of affected males and generally result in gynecomastia, short stature, and advanced bone age. Peutz-Jeghers syndrome is a condition caused by mutations in the gene for LKB1, which is the main upstream kinase for AMPK. As a consequence of the regulatory mechanisms described below, this results in elevated aromatase expression in the breast and in germ cells. In the case of boys, this results in gynecomastia and oestrogen-producing Sertoli cell tumors (Coen et al. 1991, Ham et al. 2013). A severe case of an ectopic source of oestrogen was described in a boy with a hepatocellular carcinoma that secreted large quantities of oestradiol (Agarwal et al. 1998). This resulted in short stature due to

Published by Bioscientifica Ltd. 
premature epiphyseal closure, advanced bone age, severe gynecomastia, and low testosterone. Removal of the tumor resulted in normalization of the blood parameters.

\section{Aromatase expression and breast cancer}

\section{Source of oestrogens}

The incidence of breast cancer is higher in postmenopausal women than in younger women, and $80 \%$ of these tumors are ER positive. The question arises as to the source of oestrogen that drives this tumor growth, because the ovaries cease to synthesize oestrogens at the time of menopause and circulating levels postmenopausally are very low. There is increased recognition that the risk of several cancers including breast cancer is increased with obesity. Obesity is also now recognized to be an inflammatory condition. The adipose tissue is the largest source of oestrogens in postmenopausal women and this explains why circulating levels increase with increased obesity in these women. Much evidence points to this as the source of oestrogen driving breast cancer development in these women. Correlations of plasma oestradiol levels with the expression of oestrogen-regulated genes in breast cancer tissue support this concept (Dunbier et al. 2008, Lonning et al. 2011). A number of reports show a correlation between circulating levels of oestrogens and breast cancer risk (see below), but this does not mean that circulating levels are necessarily the drivers of breast cancer; rather they reflect the ongoing synthesis of oestrogens within the adipose tissue, some of which gets into the circulation. In fibroblasts surrounding a breast tumor, aromatase expression is increased several-fold, and this is largely due to promoter II action driven by PGE2, which is an inflammatory mediator (Fig. 6). Studies on the regulation of aromatase expression in human breast adipose stromal cells have led to the identification of adipose-specific factors in this role. Central to this role is AMPK, which is recognized as a master regulator of energy homeostasis (Brown et al. 2009; Fig. 7). Briefly, AMPK inhibits promoter II-driven aromatase gene expression by sequestering the CREB-activating factor CRTC in the cytoplasm, thus preventing it from entering the nucleus. It was found that that leptin (secreted by adipose tissue in proportion to adiposity) inhibits AMPK activity and, hence, allows CRTC to enter the nucleus, activate CREB, and activate aromatase gene expression. By contrast, adiponectin, in which levels are inversely proportional to adiposity, stimulates AMPK and, hence, inhibits aromatase expression. Metformin acts in a similar fashion

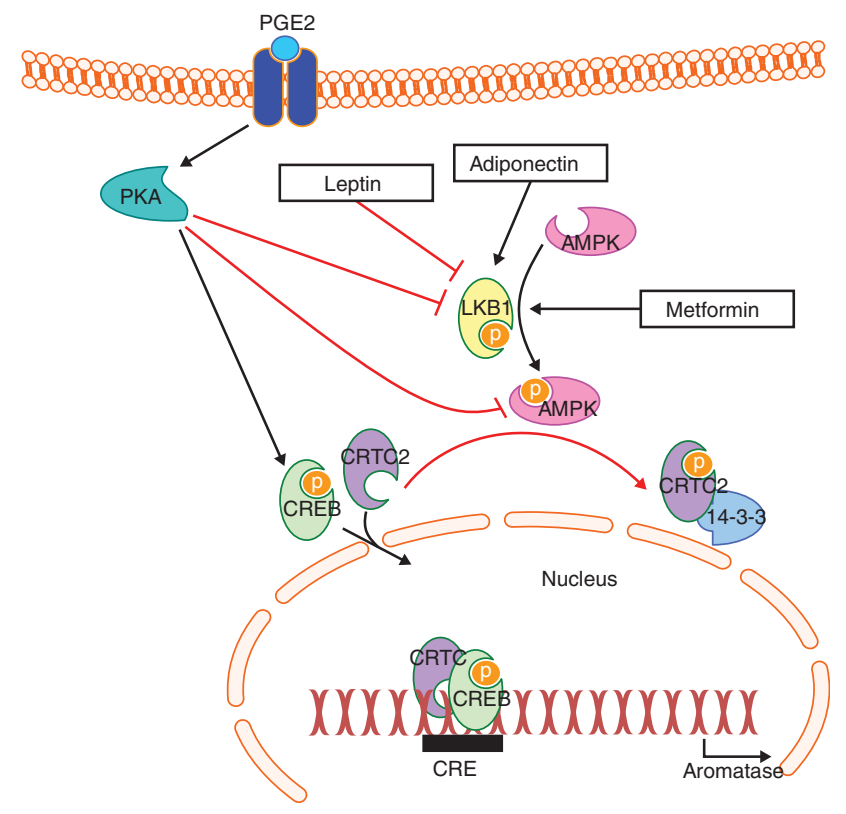

Figure 7

Regulation of aromatase gene expression in adipose tissue showing the stimulatory actions of PGE2 and leptin and the inhibitory role of adiponectin and metformin. These actions converge on the LKB1/AMPK pathway. Reproduced, with permission, from Simpson ER \& Brown KA (2013) Minireview: Obesity and breast cancer: a tale of inflammation and dysregulated metabolism. Molecular Endocrinology 27 715-725.

to adiponectin to stimulate AMPK and inhibit aromatase expression, hence, providing one mechanism for the observations that metformin is protective against breast cancer (Brown et al. 2010). Thus, we see that AMPK plays a central inhibitory role in the mechanisms whereby inflammation and obesity regulate aromatase expression in the breast. These results immediately provide a new and commanding explanation for the link between obesity, aging, and breast cancer risk. First, obesity results in a decrease in circulating adiponectin and an increase in leptin. Second, obesity results in the formation of inflammatory mediators (Subbaramaiah et al. 2012), notably PGE2. Each of these would in turn result in a decrease in the activity of the LKB1/AMPK pathway in breast adipose resulting in increased expression of aromatase. The resulting increase in oestrogen formation in the breast would lead to an increased breast cancer proliferation.

\section{Mechanisms of oestrogen associated carcinogenesis}

A large body of data suggests that oestrogens are associated with the development of breast cancer (Santen et al. 2007).

Published by Bioscientifica Ltd 


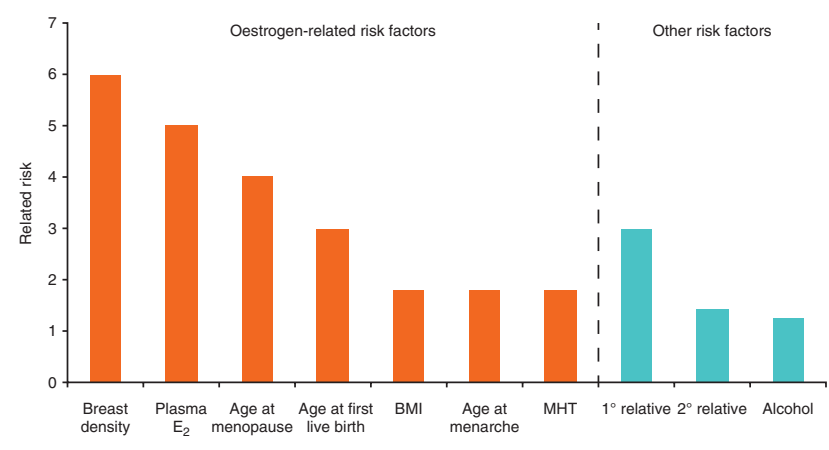

Figure 8

Relative risk of breast cancer based on various clinical factors. $E_{2}$, oestradiol. Reproduced, with permission, from Santen RJ, Boyd NF, Chlebowski RT, Cummings S, Cuzick J, Dowsett M, Easton D, Forbes JF, Key T, Hankinson SE, Howell A, Ingle J \& Breast Cancer Prevention Collaborative Group (2007) Critical assessment of new risk factors for breast cancer: considerations for development of an improved risk prediction model. Endocrine-Related Cancer 14 169-187.

This conclusion is based on the observations that several oestrogen-related events such as early menarche, age at menopause, plasma oestrogen levels, BMI, and menopausal hormone therapy (MHT) are all associated with an increased risk of breast cancer (Fig. 8; Santen et al. 2007). Two large multi-center studies demonstrated a linear relationship between breast cancer risk and increasing oestradiol (Fig. 9; Key et al. 2002, Kaaks et al. 2005). These data relate primarily to postmenopausal women as it is difficult to assess oestrogen levels in premenopausal women due to the marked fluctuations during the menstrual cycle (Santen et al. 2007).

How oestrogens cause breast cancer has been a controversial issue. Most believe that the pro-proliferative effects of oestrogen cause an increase in mutational errors during the process of cell replication and that an accumulation of these mutations, when unrepaired, results in breast cancer (Preston-Martin et al. 1990, 1993). A more controversial concept suggests that metabolites of oestrogen are directly genotoxic (Rogan et al. 2003, Cavalieri et al. 2006, Yager \& Davidson 2006, Saeed et al. 2007, Gaikwad et al. 2008, 2009, Yue et al. 2010, Yager 2012). Oestrogens are metabolized initially to catechol oestrogens and then oxidized to oestrogen quinones, which can bind directly to adenine and guanine. These adducts are unstable and oestradiol adenine and oestradiol guanine are released from the DNA backbone, a process called 'depurination', Fig. 10 shows the two most important compounds released during depurination.

'Error prone' DNA repair then occurs to repair the depurinated sites and this results in point mutations. In addition, the quinones can be back converted to catechol oestrogens via the enzyme quinone reductase. This process results in a redox cycle starting with the conversion of catechol oestrogens to quinones and then via quinone reductase, the back conversion to catechol oestrogens. Each transversion of the cycle yields oxygenfree radicals, which oxidize guanine to 8-oxo-guanine, a compound that also undergoes depurination. Together, these two pathways initiate mutations that, if unrepaired, can accumulate and ultimately cause breast cancer. A body of invitro and invivo data support this genotoxic pathway. Studies in the ER $\alpha \mathrm{KO} / \mathrm{Wnt} 1$ knock-in mouse provide the strongest evidence for the ER-independent genotoxic effects (Yue et al. 2010). These studies suggest that both ER-dependent and ER-independent genotoxic effects are mechanistic mediators of oestrogen-induced breast cancer. Recent data suggest that both the oestrogen metabolism-related genotoxic pathways and aromatase are increased by BRCA1 mutations and contribute to breast cancer in patients harboring mutations of this gene (Savage et al. 2014). The current state of knowledge regarding these mechanisms is incomplete and further work will be required for a full understanding of the processes involved.

\section{Endometrial cancer}

Oestrogen is also considered to be causally related to endometrial cancer. The most compelling data are the increased incidence of endometrial cancer in postmenopausal women taking unopposed oestrogen. Another risk

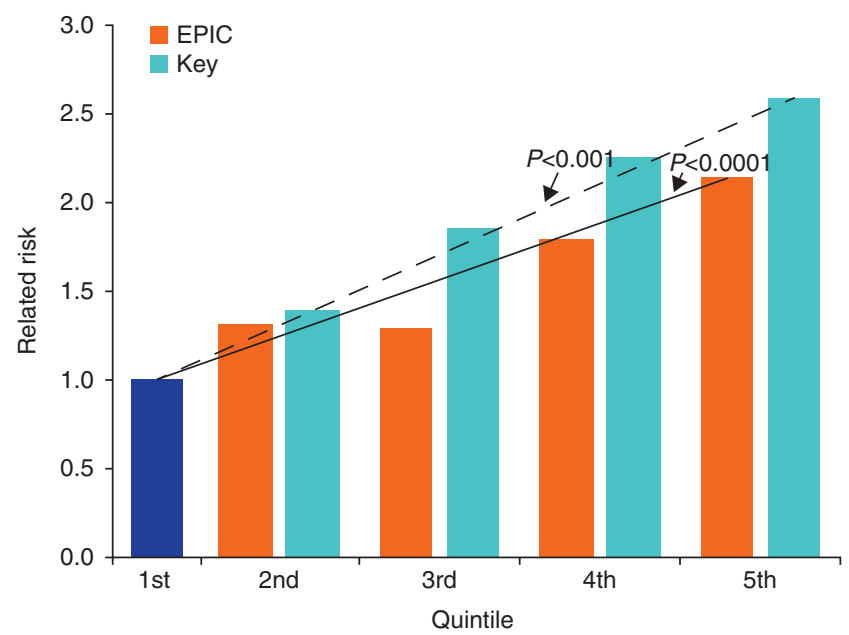

Figure 9

The levels of oestradiol are correlated with the relative risk of breast cancer. Data from Key et al. 2002 and Kaaks et al. 2005.

Published by Bioscientifica Ltd 

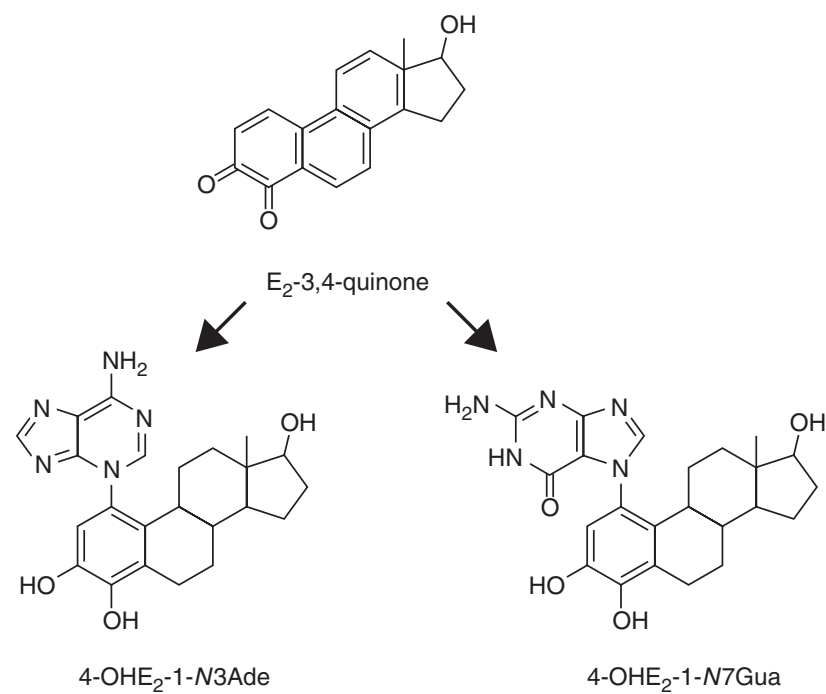

Figure 10

The oestradiol-adenine and oestradiol-guanine adducts that have been released from DNA, a process called depurination. $E_{2}$, oestradiol. Data from Cavalieri et al. (2006).

factor for endometrial cancer also relates to excess oestrogen production. The degree of obesity is linearly related to the expression of aromatase, the enzyme converting androgens to oestrogens. This causes a linear increase in oestradiol levels and an increase in endometrial cancer. Polycystic ovarian syndrome, which is associated both with obesity and with anovulation and lack of progesterone production, is also a risk factor for endometrial cancer. The mechanisms are likely similar to those for breast cancer involving both ER-dependent and ER-independent pathways. Because of the effects of unopposed oestrogen, anovulatory women with PCOS or obesity are usually given cyclic progestogen to prevent the development of endometrial cancer.

\section{Clinical therapeutic aspects of oestrogens}

\section{Oestrogen and breast cancer therapies}

Agents targeted at oestrogen and its receptor for treatment of breast cancer are multiple. A full description of each and the nuances of therapy are beyond the scope of this history, and only the general principles will be outlined here. Human breast cancer can be divided into hormonedependent and -independent subtypes. The first observation that certain breast cancers respond to oestrogen deprivation came from the study of Beatson (1896). He removed the ovaries from three premenopausal women with breast cancer and observed objective but temporary responses. This pioneering study motivated investigators to develop several means of manipulating the hormonal milieu as a treatment of breast cancer. Initially, this involved surgical ablative therapies including oophorectomy for pre-menopausal women, adrenalectomy for postmenopausal, and hypophysectomy for both. Later the concept of hormone additive therapy ensued and women were treated successfully with oestrogens, androgens, and progestins (Santen et al. 1990). Later, more specific therapies were developed including gonadotropin-releasing hormone agonists to reduce oestrogens via a medical oophorectomy and selective ER modulators such as the anti-oestrogen tamoxifen. The development of $\mathrm{ER} \alpha$ measurements by Elwood Jensen to predict who would respond to these therapies represented a major breakthrough and allowed these therapies to be specifically targeted (Block et al. 1978).

At the time that tamoxifen was being developed, Harry and Angela Brodie raised the hypothesis that aromatase would be an excellent target for breast cancer therapy. They began synthesizing a series of steroidal compounds with aromatase inhibitory properties (Brodie et al. 1977, 1981, Marsh et al. 1985, Dowsett et al. 1987). Pentii Siiteri also examined the non-steroidal compound, AG, and demonstrated that it was a potent aromatase inhibitor (Bolton \& Siiteri 1969). Several groups then demonstrated that this agent, in combination with a glucocorticoid, blocked oestradiol production effectively in postmenopausal women and caused partial and complete, but time-limited, breast tumor regressions (Cash et al. 1967, Griffiths et al. 1973, Santen et al. 1974, Newsome et al. 1977, 1978, Santen et al. 1978a, 1981, Santen 1981). The group working at Penn State demonstrated directly with isotopic kinetic studies in postmenopausal women that AG blocked aromatase by $95-98 \%$ (Santen et al. 1978b). This same group then showed efficacy in 129 women with breast cancer and that this therapy was as effective as surgical adrenalectomy (Santen et al. 1981, 1982) and tamoxifen (Lipton et al. 1982). These studies stimulated the later development of second- and third-generation aromatase inhibitors, which were more potent and less toxic than AG. The currently approved third-generation aromatase inhibitors are commonly used and have been shown to be more effective than tamoxifen.

The hormone additive approach, largely neglected on development of inhibitors of oestrogen synthesis or action, has now been reconsidered for a highly selected group of postmenopausal women - namely, those who

Published by Bioscientifica Ltd. 
had responded to first-line hormonal therapy (Song et al. 2001, Lewis et al. 2005). The underlying basis for this approach is that long-term deprivation of oestrogen causes breast cancer cells to respond to exogenous oestrogen with apoptosis. This pro-apoptotic process involves both intrinsic and extrinsic death pathways and most recently has been shown to involve AMPK and its downstream targets FoxO3, Fas ligand, Gadd $45 \alpha$, and BIM (Chen et al. 2015). Several studies demonstrate objective tumor regressions, often prolonged, in women receiving exogenous oestrogen (Ellis et al. 2009, Lonning 2009). This proapoptotic pathway may also explain why oestrogen used alone without a concomitant progestin in the Women's Health Initiative (WHI) study caused a paradoxical reduction in breast cancer in women lacking a uterus (Anderson et al. 2012).

\section{Oestrogen therapy and menopause}

It was recognized in the mid- and late-19th century that removal of the ovaries can result in a panoply of symptoms. Dr Robert Battey introduced bilateral oophorectomy for the treatment of a number of non-specific symptoms articulated by pre-menopausal women (Watkins 2007). While based on faulty scientific reasoning and resulting in significant operative deaths (estimated to be one in five), this therapy highlighted the fact that the ovaries make some type of substance that exerted systemic effects. Their removal resulted in menopausal symptoms. By the early 1900s, ovarian extracts had been utilized as a means to alleviate the symptoms of both surgical and natural menopause After Doisy and his group had isolated and characterized oestradiol (dihydrotheelin; Huffman et al. 1940), pharmaceutical companies synthesized oestrogenic compounds such as diethylstilbestrol or isolated oestrogens from horse urine and formulated this as Premarin. As studies showed that menopause was associated with a precipitous fall of oestrogen, the concept of hormone replacement therapy (HRT) was introduced and considered analogous to thyroid replacement therapy for hypothyroidism. During the 1980s, a substantial percentage of postmenopausal women utilized oestrogen alone. However, when studies demonstrated an increase in uterine cancer associated with 'unopposed oestrogen', a progestin was added to protect the uterus from cancer in postmenopausal women. As recommended in an influential book by Robert Wilson (Wilson 1968), in the mid-1980s, the medical community generally believed that this therapy was beneficial for the treatment of menopausal symptoms and might also prevent fractures and heart disease.

The concept gradually arose, primarily in the USA, that clinical studies were needed to determine how women specifically respond to certain medicines. Bernadine Healy, then the head of the National Institutes of Health in the USA, pointed out that most pharmaceutical studies were carried out primarily in men. She emphasized that HRT had not been studied with state-of-the-art clinical trials and championed a placebo-controlled, randomized trial of hormones therapy for postmenopausal women, the WHI study. This required nearly 10 years to complete and the results were highly unexpected by the medical community and their patients. The first publication in 2002 with conjugated equine oestrogen (CEE; Premarin) plus medroxyprogesterone acetate (MPA) as the progestin reported highly unexpected results. Not only did HRT not prevent heart disease but also it appeared to increase this by $26 \%$ (relative risk) and at the same time caused a $25 \%$ increase in breast cancer. Data from the oestrogen-alone arm of the WHI in women having undergone a hysterectomy were reported shortly after, showing an increase in stroke and no reduction of heart disease (Anderson et al. 2004).

These two WHI studies resulted in an $80 \%$ decrease in the use of HRT in the USA and worldwide (Tsai et al. 2011). As the studies were further analyzed, several key points arose that provided insight into the findings and identified more clearly when the benefits of HRT might outweigh the risks. The first observation was that the average age of women in the WHI was 63 and the majority of women face the decision of taking MHT shortly after menopause at an average age of 51 when their symptoms are greatest. Secondly, the absolute risk of heart disease or stroke in women at age 51 is much lower than at age 63 . The data from the WHI were reported generally as relative risk and not absolute or excess risk. The WHI used CEE and MPA as HRT. Many commentators questioned whether the results actually represented class effects of an oestrogen plus a progestin or whether other oestrogen and progestin preparations might have differing effects. A follow-up WHI study in October 2013 examined the effects of CEE alone (E) or CEE plus MPA $(\mathrm{E}+\mathrm{P})$ in women less than age 60 or between ages 50 and 59. In this subset of women, there was no statistically significant increase in heart disease with $\mathrm{E}+\mathrm{P}$ and a significant trend toward reduction in those using $\mathrm{E}$ alone. Quite surprising was the statistically significant reduction in the risk of breast cancer in the women receiving oestrogen alone (Anderson et al. 2012; Fig. 11). With this follow-up study,

Published by Bioscientifica Ltd. 


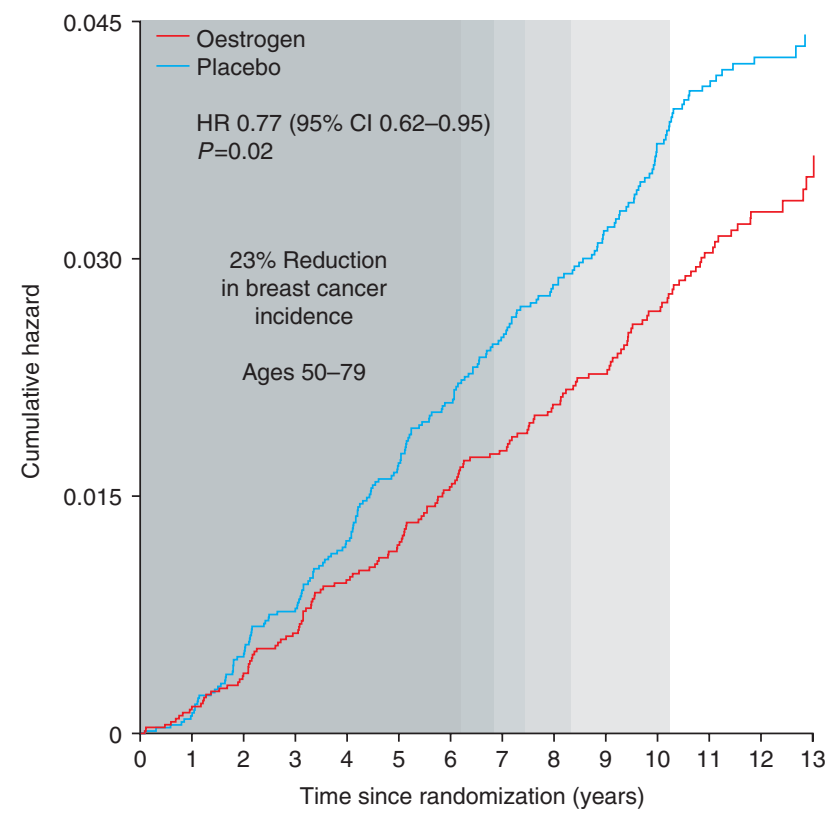

\section{Figure 11}

The risk of breast cancer in women receiving placebo or conjugated equine oestrogen in the Women's Health Initiative study. Reprinted with permission from Elsevier (Lancet Oncology; Anderson GL, Chlebowski RT, Aragaki AK, Kuller LH, Manson JE, Gass M, Bluhm E, Connelly S, Hubbell FA, Lane D, Martin L, Ockene J, Rohan T, Schenken R \& Wactawski-Wende J; 2012; Conjugated equine oestrogen and breast cancer incidence and mortality in postmenopausal women with hysterectomy: extended followup of the Women's Health Initiative randomised placebo-controlled trial; volume 13; pages 476-486).

the pendulum is swinging back toward the use of hormonal therapy.

As the WHI is the largest randomized, controlled trial of $\mathrm{E}$ or $\mathrm{E}+\mathrm{P}$ vs placebo, much weight has been placed on its results, particularly in the USA. A reasonable case can be made that other preparations such as oestradiol with crystalline progesterone may be safer, particularly with respect to breast cancer. However, these proponents must rely on observational data for their conclusions. The comprehensive scientific statement on MHT published by the Endocrine Society compared the available studies and concluded that most oral forms of oestrogen and progestin exhibit class effects with respect to breast cancer and heart disease with the exception of oestradiol plus crystalline progesterone (Santen et al. 2010).

Most menopause society guidelines now agree that the women who would benefit from hormonal therapy should be judged based on the individual characteristics of the patient. Data to support these conclusions come from multiple sources as reviewed extensively (Santen et al. 2010) as well as from the a 13-year follow-up of the WHI study (Manson et al. 2013). For this reason, the term HRT, which implies that all women should accept this therapy, has been replaced by the term MHT. Guidelines from the Endocrine Society, North American Menopause Society, International Menopause Society, and other societies are now generally in agreement about the risks and benefits of MHT. This therapy should generally be limited to symptomatic patients without an excess risk of heart disease, stroke, or breast cancer. It should not be used to prevent heart disease but may be considered as part of a management plan to prevent fractures. Vaginal oestrogens are preferable to systemic oestrogens when symptoms are limited to the genitourinary syndrome of menopause (Santen 2015). A summary of recent literature and guidelines indicates that the pendulum is now swinging back toward the use of MHT for women within 10 years of menopause onset and without moderate or high risks of breast cancer and heart disease. These principles were espoused in the recent Endocrine Society guidelines on menopause (Stuenkel et al. 2015). The choice of CEE vs oestradiol remains a matter of controversy with clear national preferences. For a full review of the scientific aspects of MHT, the see the Scientific Statement published by the Endocrine Society in 2010 and the various guidelines published by several menopause societies (Santen et al. 2010).

\section{Perspectives and challenges}

In the 80-plus years since oestrogenic substances were first isolated and characterized, clearly much has been learned about this fascinating class of compounds. Starting with their biosynthesis, the mechanism of the aromatase reaction still astonishes chemists and non-chemists alike given that this complex series of reactions occur at a single catalytic site unique among the thousands of P450 species that have been identified in the biosphere at large. Second, the structure of the aromatase gene, when first characterized, was also unique, at least at the time, in terms of the unusual complexity of multiple promoter employment that is responsible for the highly tissue-specific regulation of oestrogen expression. Third, many unexpected facets of oestrogen physiology emerged. Perhaps the least anticipated of these were the roles of oestrogens in the male, indicating functions complementary to those in the female. Moreover, many of these roles are not involved in reproduction, such as the underlying involvement of oestrogens in energy homeostasis in both sexes and, perhaps especially, the unexpected role of oestrogens in male bone physiology. Going forward from a clinical

Published by Bioscientifica Ltd 
perspective, the main challenges are to differentiate the positive functions of oestrogens from their pathophysiologic roles. For example, the actions of oestrogens in the brain and cardiovascular system are still controversial. How to manage oestrogen-dependent cancers without depriving the patient of the beneficial effects of oestrogens is a major ongoing issue. Sorting out the good, the bad, and the unexpected roles of oestrogens will no doubt continue to challenge investigators and clinicians alike for decades to come.

\section{Declaration of interest}

The authors declare that there is no conflict of interest that could be perceived as prejudicing the impartiality of the review.

\section{Funding}

This review did not receive any specific grant from any funding agency in the public, commercial or not-for-profit sector.

\section{References}

Agarwal VR, Takayama K, Van Wyk JJ, Sasano H, Simpson ER \& Bulun SE 1998 Molecular basis of severe gynecomastia associated with aromatase expression in a fibrolamellar hepatocellular carcinoma. Journal of Clinical Endocrinology and Metabolism 83 1797-1800.

Albright F \& Ellsberg R 1990 Uncharted seas, pp 3-95. Portland, OR, USA: Kalmia Press.

Allen E 1924 The hormone of the ovarian follicle; its localization and action in test animals, and additional points bearing upon the internal secretion of the ovary. American Journal of Anatomy 84 133-154. (doi:10.1002/aja.1000340104)

Anderson GL, Limacher M, Assaf AR, Bassford T, Beresford SA, Black H, Bonds D, Brunner R, Brzyski R, Caan B et al. 2004 Effects of conjugated equine oestrogen in postmenopausal women with hysterectomy: the Women's Health Initiative randomized controlled trial. Journal of the American Medical Association 291 1701-1712. (doi:10.1001/jama.291. 14.1701)

Anderson GL, Chlebowski RT, Aragaki AK, Kuller LH, Manson JE, Gass M, Bluhm E, Connelly S, Hubbell FA, Lane D et al. 2012 Conjugated equine oestrogen and breast cancer incidence and mortality in postmenopausal women with hysterectomy: extended follow-up of the Women's Health Initiative randomised placebo-controlled trial. Lancet. Oncology 13 476-486. (doi:10.1016/S1470-2045(12)70075-X)

Arnal JF, Fontaine C, Abot A, Valera MC, Laurell H, Gourdy P \& Lenfant F 2013 Lessons from the dissection of the activation functions (AF-1 and $\mathrm{AF}-2$ ) of the oestrogen receptor $\alpha$ in vivo. Steroids 78 576-582. (doi:10. 1016/j.steroids.2012.11.011)

Beatson GT 1896 On the treatment of inoperable cases of carcinoma of the mamma: suggestions for a new method of treatment, with illustrative cases. Lancet 2 162-165. (doi:10.1016/S0140-6736(01)72384-7)

Bender CM, Merriman JD, Gentry AL, Ahrendt GM, Berga SL, Brufsky AM, Casillo FE, Dailey MM, Erickson KI, Kratofil FM et al. 2015 Patterns of change in cognitive function with anastrozole therapy. Cancer 121 2627-2636. (doi:10.1002/cncr.29393)

Block GE, Ellis RS, DeSombre E \& Jensen E 1978 Correlation of estrophilin content of primary mammary cancer to eventual endocrine treatment. Annals of Surgery 188 372-376. (available at: http://journals.lww.
com/annalsofsurgery/Abstract/1978/09000/Correlation_of_Estrophilin_ Content_of_Primary.12.aspx)

Bolton S \& Siiteri PK 1969 Studies of aromatizing enzymes of the placenta. In 16th Annual Meeting of the Society for Gynecologic Investigation, March 20-21, p 37. Denver, CO, USA: Society for Gynecologic Investigation.

Brodie HJ, Hayano M \& Gut M 1962 The stereochemical course of catalytic hydrogenation of ring A unsaturated steroids. Journal of the American Chemical Society 84 3766-3767. (doi:10.1021/ ja00878a033)

Brodie HJ, Kripalani KJ \& Possanza G 1969 Studies on the mechanism of oestrogen biosynthesis. VI. The stereochemistry of hydrogen elimination at C-2 during aromatization. Journal of the American Chemical Society 91 1241-1242. (doi:10.1021/ja01033a050)

Brodie AM, Schwarzel WC, Shaikh AA \& Brodie HJ 1977 The effect of an aromatase inhibitor, 4-hydroxy-4-androstene-3,17-dione, on estrogendependent processes in reproduction and breast cancer. Endocrinology 100 1684-1695. (doi:10.1210/endo-100-6-1684)

Brodie AM, Garrett WM, Hendrickson JR, Tsai-Morris CH, Marcotte PA \& Robinson CH 1981 Inactivation of aromatase in vitro by 4-hydroxy4-androstene-3,17-dione and 4-acetoxy-4-androstene-3,17-dione and sustained effects in vivo. Steroids 38 693-702. (doi:10.1016/0039-128X (81)90087-8)

Brown KA, McInnes KJ, Hunger NI, Oakhill JS, Steinberg GR \& Simpson ER 2009 Subcellular localization of cyclic AMP-responsive element binding protein-regulated transcription coactivator 2 provides a link between obesity and breast cancer in postmenopausal women. Cancer Research 69 5392-5399. (doi:10.1158/0008-5472.CAN-09-0108)

Brown KA, Hunger NI, Docanto M \& Simpson ER 2010 Metformin inhibits aromatase expression in human breast adipose stromal cells via stimulation of AMP-activated protein kinase. Breast Cancer Research and Treatment 123 591-596. (doi:10.1007/s10549-010-0834-y)

Bulun SE 2014 Aromatase and oestrogen receptor $\alpha$ deficiency. Fertility and Sterility 101 323-329. (doi:10.1016/j.fertnstert.2013.12.022)

Bulun SE, Takayama K, Suzuki T, Sasano H, Yilmaz B \& Sebastian S 2004 Organization of the human aromatase p450 (CYP19) gene. Seminars in Reproductive Medicine 22 5-9. (doi:10.1055/s-2004-823022)

Butenandt A 1929 Uber progynon ein krytallisiertes weibliches exualhormon. Die Naturwissenschaften 17 879. (doi:10.1007/BF01506919)

Cash R, Brough AJ, Cohen MN \& Satoh PS 1967 Aminoglutethimide (Elipten-Ciba) as an inhibitor of adrenal steroidogenesis: mechanism of action and therapeutic trial. Journal of Clinical Endocrinology and Metabolism 27 1239-1248. (doi:10.1210/jcem-27-9-1239)

Cavalieri E, Chakravarti D, Guttenplan J, Hart E, Ingle J, Jankowiak R, Muti P, Rogan E, Russo J, Santen R et al. 2006 Catechol oestrogen quinones as initiators of breast and other human cancers: implications for biomarkers of susceptibility and cancer prevention. Biochimica et Biophysica Acta 1766 63-78.

Chakraborty J, Hopkins R \& Parke DV 1972 Inhibition studies on the aromatization of androst-4-ene-3,17-dione by human placental microsomal preparations. Biochemical Journal 130 19P-20P. (doi:10.1042/bj1300019Pb)

Chambliss KL, Wu Q, Oltmann S, Konaniah ES, Umetani M, Korach KS, Thomas GD, Mineo C, Yuhanna IS, Kim SH et al. 2010 Non-nuclear oestrogen receptor $\alpha$ signaling promotes cardiovascular protection but not uterine or breast cancer growth in mice. Journal of Clinical Investigation 120 2319-2330. (doi:10.1172/JCI38291)

Chen H, Wang JP, Santen RJ \& Yue W 2015 Adenosine monophosphate activated protein kinase (AMPK), a mediator of estradiol-induced apoptosis in long-term oestrogen deprived breast cancer cells. Apoptosis 20 821-830. (doi:10.1007/s10495-015-1111-7)

Coen P, Kulin H, Ballantine T, Zaino R, Frauenhoffer E, Boal D, Inkster S, Brodie A \& Santen R 1991 An aromatase-producing sex-cord tumor resulting in prepubertal gynecomastia. New England Journal of Medicine 324 317-322. (doi:10.1056/NEJM199101 313240507)

Corbin CJ, Graham-Lorence S, McPhaul M, Mason JI, Mendelson CR \& Simpson ER 1988 Isolation of a full-length cDNA insert encoding

Published by Bioscientifica Ltd. 
human aromatase system cytochrome P-450 and its expression in nonsteroidogenic cells. PNAS 85 8948-8952. (doi:10.1073/ pnas.85.23.8948)

Couse JF, Lindzey J, Grandien K, Gustafsson JA \& Korach KS 1997 Tissue distribution and quantitative analysis of oestrogen receptor- $\alpha(\operatorname{ER} \alpha)$ and oestrogen receptor- $\beta(\mathrm{ER} \beta)$ messenger ribonucleic acid in the wild-type and ER $\alpha$-knockout mouse. Endocrinology 138 4613-4621.

Dahlman-Wright K, Cavailles V, Fuqua SA, Jordan VC, Katzenellenbogen JA, Korach KS, Maggi A, Muramatsu M, Parker MG \& Gustafsson JA 2006 International Union of Pharmacology. LXIV. Estrogen receptors. Pharmacological Reviews 58 773-781. (doi:10.1124/pr.58.4.8)

Doisy EA 1976 An autobiography. Annual Review of Biochemistry 45 1-12. (doi:10.1146/annurev.bi.45.070176.000245)

Doisy EA, Thayer S \& Veler CD 1929 The crystals of the follicular ovarian hormone. Proceedings of the Society for Experimental Biology and Medicine 27 417-419. (doi:10.3181/00379727-27-4791)

Dowsett M, Goss PE, Powles TJ, Hutchinson G, Brodie AM, Jeffcoate SL \& Coombes RC 1987 Use of the aromatase inhibitor 4-hydroxyandrostenedione in postmenopausal breast cancer: optimization of therapeutic dose and route. Cancer Research 47 1957-1961.

Dunbier AK, Anderson H, Folkerd E, Ghazoui Z, Smith IE, Ellis MJ, Dowsett M \& Neoadjuvant Letrozole Study Group 2008 Expression of oestrogen responsive genes in breast cancers correlates wtih plasma oestradiol levels in post-menopausal women. Cancer Research 6963 (31st Annual San Antonio Breast Cancer Symposium, abstract \#63, 2008).

Ellis MJ, Gao F, Dehdashti F, Jeffe DB, Marcom PK, Carey LA, Dickler MN, Silverman P, Fleming GF, Kommareddy A et al. 2009 Lower-dose vs high-dose oral oestradiol therapy of hormone receptor-positive, aromatase inhibitor-resistant advanced breast cancer: a phase 2 randomized study. Journal of the American Medical Association 302774 780. (doi:10.1001/jama.2009.1204)

Evans CT, Ledesma DB, Schulz TZ, Simpson ER \& Mendelson CR 1986 Isolation and characterization of a complementary DNA specific for human aromatase-system cytochrome P-450 mRNA. PNAS 83 6387-6391. (doi:10.1073/pnas.83.17.6387)

Favia AD, Cavalli A, Masetti M, Carotti A \& Recanatini M 2006 Threedimensional model of the human aromatase enzyme and density functional parameterization of the iron-containing protoporphyrin IX for a molecular dynamics study of heme-cysteinato cytochromes. Proteins 62 1074-1087. (doi:10.1002/prot.20829)

Filardo EJ \& Thomas P 2012 Minireview: G protein-coupled oestrogen receptor-1, GPER-1: its mechanism of action and role in female reproductive cancer, renal and vascular physiology. Endocrinology 153 2953-2962. (doi:10.1210/en.2012-1061)

Finkelstein JS, Lee H, Burnett-Bowie SA, Pallais JC, Yu EW, Borges LF, Jones BF, Barry CV, Wulczyn KE, Thomas BJ et al. 2013 Gonadal steroids and body composition, strength, and sexual function in men. New England Journal of Medicine 369 1011-1022. (doi:10.1056/ NEJMoa1206168)

Flamini MI, Sanchez AM, Genazzani AR \& Simoncini T 2011 Estrogen regulates endometrial cell cytoskeletal remodeling and motility via focal adhesion kinase. Fertility and Sterility 95 722-726. (doi:10.1016/ j.fertnstert.2010.08.039)

Gaikwad NW, Yang L, Muti P, Meza JL, Pruthi S, Ingle JN, Rogan EG \& Cavalieri EL 2008 The molecular etiology of breast cancer: evidence from biomarkers of risk. International Journal of Cancer 122 1949-1957. (doi:10.1002/ijc.23329)

Gaikwad NW, Yang L, Weisenburger DD, Vose J, Beseler C, Rogan EG \& Cavalieri EL 2009 Urinary biomarkers suggest that estrogen-DNA adducts may play a role in the aetiology of non-Hodgkin lymphoma. Biomarkers 14 502-512. (doi:10.3109/13547500903121715)

Ghosh D, Griswold J, Erman M \& Pangborn W 2009 Structural basis for androgen specificity and oestrogen synthesis in human aromatase. Nature 457 219-223. (doi:10.1038/nature07614)
Graham-Lorence S, Amarneh B, White RE, Peterson JA \& Simpson ER 1995 A three-dimensional model of aromatase cytochrome P450. Protein Science 4 1065-1080. (doi:10.1002/pro.5560040605)

Griffiths CT, Hall TC, Saba Z, Barlow JJ \& Nevinny HB 1973 Preliminary trial of aminoglutethimide in breast cancer. Cancer 32 31-37. (doi:10.1002/ 1097-0142(197307)32:1<31::AID-CNCR2820320104>3.0.CO;2-5)

Haas E, Bhattacharya I, Brailoiu E, Damjanovic M, Brailoiu GC, Gao X, Mueller-Guerre L, Marjon NA, Gut A, Minotti R et al. 2009 Regulatory role of $\mathrm{G}$ protein-coupled oestrogen receptor for vascular function and obesity. Circulation Research 104 288-291. (doi:10.1161/CIRCRESAHA. 108.190892)

Hall PF, Chen S, Nakajin S, Shinoda M \& Shively JE 1987 Purification and characterization of aromatase from human placenta. Steroids $5037-50$. (doi:10.1016/0039-128X(83)90060-0)

Ham S, Meachem SJ, Choong CS, Charles AK, Baynam GS, Jones TW, Samarajeewa NU, Simpson ER \& Brown KA 2013 Overexpression of aromatase associated with loss of heterozygosity of the STK11 gene accounts for prepubertal gynecomastia in boys with Peutz-Jeghers syndrome. Journal of Clinical Endocrinology and Metabolism 98 E1979-E1987. (doi:10.1210/jc.2013-2291)

Hamilton KJ, Arao Y \& Korach KS 2014 Estrogen hormone physiology: reproductive findings from oestrogen receptor mutant mice. Reproductive Biology 14 3-8. (doi:10.1016/j.repbio.2013.12.002)

Harada N 1988 Cloning of a complete cDNA encoding human aromatase: immunochemical identification and sequence analysis. Biochemical and Biophysical Research Communications 156 725-732. (doi:10.1016/S0006291X(88)80903-3)

Harada N, Yamada K, Saito K, Kibe N, Dohmae S \& Takagi Y 1990 Structural characterization of the human oestrogen synthetase (aromatase) gene. Biochemical and Biophysical Research Communications 166 365-372. (doi:10.1016/0006-291X(90)91954-Q)

Harrington WR, Kim SH, Funk CC, Madak-Erdogan Z, Schiff R, Katzenellenbogen JA \& Katzenellenbogen BS 2006 Estrogen dendrimer conjugates that preferentially activate extranuclear, nongenomic versus genomic pathways of oestrogen action. Molecular Endocrinology 20 491-502. (doi:10.1210/me.2005-0186)

Hickey GJ, Krasnow JS, Beattie WG \& Richards JS 1990 Aromatase cytochrome P450 in rat ovarian granulosa cells before and after luteinization: adenosine $3^{\prime}, 5^{\prime}$-monophosphate-dependent and independent regulation. Cloning and sequencing of rat aromatase cDNA and 5' genomic DNA. Molecular Endocrinology 4 3-12. (doi:10.1210/ mend-4-1-3)

Hong Y, Yu B, Sherman M, Yuan YC, Zhou D \& Chen S 2007 Molecular basis for the aromatization reaction and exemestane-mediated irreversible inhibition of human aromatase. Molecular Endocrinology 21 401-414. (doi:10.1210/me.2006-0281)

Hong Y, Li H, Ye J, Miki Y, Yuan YC, Sasano H, Evans DB \& Chen S 2009 Epitope characterization of an aromatase monoclonal antibody suitable for the assessment of intratumoral aromatase activity. PLoS ONE 4 e8050. (doi:10.1371/journal.pone.0008050)

Hong Y, Li H, Yuan YC \& Chen S 2010 Sequence-function correlation of aromatase and its interaction with reductase. Journal of Steroid Biochemistry and Molecular Biology 118 203-206. (doi:10.1016/j.jsbmb. 2009.11.010)

Huffman MN, Thayer SA \& Doisy EA 1940 The isolation of $\alpha$-dihydrotheelin from human placenta. Journal of Biological Chemistry 133 567-571.

Kaaks R, Rinaldi S, Key TJ, Berrino F, Peeters PH, Biessy C, Dossus L, Lukanova A, Bingham S, Khaw KT et al. 2005 Postmenopausal serum androgens, oestrogens and breast cancer risk: the European prospective investigation into cancer and nutrition. Endocrine-Related Cancer 12 1071-1082. (doi:10.1677/erc.1.01038)

Kellis JT Jr \& Vickery LE 1987 Purification and characterization of human placental aromatase cytochrome P-450. Journal of Biological Chemistry $2624413-4420$.

Published by Bioscientifica Ltc. 
Key T, Appleby P, Barnes I, Reeves G \& Endogenous Hormones and Breast Cancer Collaborative Group 2002 Endogenous sex hormones and breast cancer in postmenopausal women: reanalysis of nine prospective studies. Journal of the National Cancer Institute 94 606-616. (doi:10.1093/jnci/94.8.606)

Kim JK \& Levin ER 2006 Estrogen signaling in the cardiovascular system. Nuclear Receptor Signaling 4 e013.

Koymans LM, Moereels H \& Vanden BH 1995 A molecular model for the interaction between vorozole and other non-steroidal inhibitors and human cytochrome P450 19 (P450 aromatase). Journal of Steroid Biochemistry and Molecular Biology 53 191-197. (doi:10.1016/09600760(95)00033-V)

Labrie F 2015 All sex steroids are made intracellularly in peripheral tissues by the mechanisms of intracrinology after menopause. Journal of Steroid Biochemistry and Molecular Biology 145 133-138. (doi:10.1016/j.jsbmb. 2014.06.001)

Laughton CA, Zvelebil MJ \& Neidle S 1993 A detailed molecular model for human aromatase. Journal of Steroid Biochemistry and Molecular Biology 44 399-407. (doi:10.1016/0960-0760(93)90243-P)

Levin ER 2009 Hormone action and breast cancer. Cancer Treatment and Research 147 1-10.

Levin ER 2014a Extranuclear oestrogen receptor's roles in physiology: lessons from mouse models. American Journal of Physiology. Endocrinology and Metabolism 307 E133-E140. (doi:10.1152/ajpendo. 00626.2013

Levin ER 2014b Translating extranuclear steroid receptor signaling to clinical medicine. Hormones \& Cancer 5 140-145. (doi:10.1007/s12672014-0179-9)

Levin ER 2015 Extranuclear steroid receptors are essential for steroid hormone actions. Annual Review of Medicine 66 271-280. (doi:10.1146/ annurev-med-050913-021703)

Lewis JS, Osipo C, Meeke K \& Jordan VC 2005 Estrogen-induced apoptosis in a breast cancer model resistant to long-term oestrogen withdrawal. Journal of Steroid Biochemistry and Molecular Biology 94 131-141. (doi:10.1016/j.jsbmb.2004.12.032)

Li Y, Wang JP, Santen RJ, Kim TH, Park H, Fan P \& Yue W 2010 Estrogen stimulation of cell migration involves multiple signaling pathway interactions. Endocrinology 151 5146-5156. (doi:10.1210/ en.2009-1506)

Lipton A, Harvey HA, Santen RJ, Boucher A, White D, Bernath A, Dixon R, Richards G \& Shafik A 1982 A randomized trial of aminoglutethimide versus tamoxifen in metastatic breast cancer. Cancer 50 2265-2268. (doi:10.1002/1097-0142(19821201)50:11<2265::AID CNCR2820501106>3.0.CO;2-)

Lonning PE 2009 Additive endocrine therapy for advanced breast cancer back to the future. Acta Oncologica 48 1092-1101. (doi:10.3109/ 02841860903117816)

Lonning PE, Haynes BP, Straume AH, Dunbier A, Helle H, Knappskog S \& Dowsett M 2011 Exploring breast cancer oestrogen disposition: the basis for endocrine manipulation. Clinical Cancer Research 17 4948-4958. (doi:10.1158/1078-0432.CCR-11-0043)

Madak-Erdogan Z, Kieser KJ, Kim SH, Komm B, Katzenellenbogen JA \& Katzenellenbogen BS 2008 Nuclear and extranuclear pathway inputs in the regulation of global gene expression by oestrogen receptors. Molecular Endocrinology 22 2116-2127. (doi:10.1210/me.2008-0059)

Maffei L, Murata Y, Rochira V, Tubert G, Aranda C, Vazquez M, Clyne CD, Davis S, Simpson ER \& Carani C 2004 Dysmetabolic syndrome in a man with a novel mutation of the aromatase gene: effects of testosterone, alendronate, and oestradiol treatment. Journal of Clinical Endocrinology and Metabolism 89 61-70. (doi:10.1210/jc.2003-030313)

Magnani L \& Lupien M 2014 Chromatin and epigenetic determinants of oestrogen receptor $\alpha$ (ESR1) signaling. Molecular and Cellular Endocrinology 382 633-641. (doi:10.1016/j.mce.2013.04.026)

Mahendroo MS, Means GD, Mendelson CR \& Simpson ER 1991 Tissuespecific expression of human P-450AROM. The promoter responsible for expression in adipose tissue is different from that utilized in placenta. Journal of Biological Chemistry 266 11276-11281.

Manson JE, Chlebowski RT, Stefanick ML, Aragaki AK, Rossouw JE, Prentice RL, Anderson G, Howard BV, Thomson CA, LaCroix AZ et al. 2013 Menopausal hormone therapy and health outcomes during the intervention and extended poststopping phases of the Women's Health Initiative randomized trials. Journal of the American Medical Association 310 1353-1368. (doi:10.1001/jama.2013.278040)

Marjon NA, Hu C, Hathaway HJ \& Prossnitz ER 2014 G protein-coupled oestrogen receptor regulates mammary tumorigenesis and metastasis. Molecular Cancer Research 12 1644-1654. (doi:10.1158/1541-7786. MCR-14-0128-T)

Marsh DA, Brodie HJ, Garrett W, Tsai-Morris CH \& Brodie AM 1985 Aromatase inhibitors. Synthesis and biological activity of androstenedione derivatives. Journal of Medicinal Chemistry 28 788-795. (doi:10.1021/jm00383a017)

McPhaul MJ, Noble JF, Simpson ER, Mendelson CR \& Wilson JD 1988 The expression of a functional cDNA encoding the chicken cytochrome P-450arom (aromatase) that catalyzes the formation of oestrogen from androgen. Journal of Biological Chemistry 263 16358-16363.

Means GD, Mahendroo MS, Corbin CJ, Mathis JM, Powell FE, Mendelson CR \& Simpson ER 1989 Structural analysis of the gene encoding human aromatase cytochrome P-450, the enzyme responsible for oestrogen biosynthesis. Journal of Biological Chemistry 264 19385-19391.

Means GD, Kilgore MW, Mahendroo MS, Mendelson CR \& Simpson ER 1991 Tissue-specific promoters regulate aromatase cytochrome P450 gene expression in human ovary and fetal tissues. Molecular Endocrinology 5 2005-2013. (doi:10.1210/mend-5-12-2005)

Mendelson CR, Wright EE, Evans CT, Porter JC \& Simpson ER 1985 Preparation and characterization of polyclonal and monoclonal antibodies against human aromatase cytochrome P-450 (P-450AROM), and their use in its purification. Archives of Biochemistry and Biophysics 243 480-491. (doi:10.1016/0003-9861(85)90525-9)

Meyer AS 1955 Conversion of 19-hydroxy-delta 4-androstene-3,17-dione to oestradiol by endocrine tissue. Biochimica et Biophysica Acta 17 441442. (doi:10.1016/0006-3002(55)90395-4)

Meyer AS, Hayano M, Lindberg MC, Gut M \& Rodgers OG 1955 The conversion of delta 4-androstene-3,17-dione-4-C14 and dehydroepiandrosterone by bovine adrenal homogenate preparations. Acta Endocrinologica 18 148-168.

Morato T, Hayano M, Dorfman RI \& Axelrod LR 1961 The intermediate steps in the biosynthesis of oestrogen from androgens. Biochemical and Biophysical Research Communications 6 334-338. (doi:10.1016/0006291X(61)90140-1)

Muto N \& Tan L 1985 Purification of oestrogen synthetase by highperformance liquid chromatography. Two membrane-bound enzymes from the human placenta. Journal of Chromatography 326 137-146. (doi:10.1016/S0021-9673(01)87439-2)

Newsome HH, Brown PW, Terz JJ \& Lawrence W Jr 1977 Medical and surgical adrenalectomy in patients with advanced breast carcinoma. Cancer 39 542-546. (doi:10.1002/1097-0142(197702)39:2<542::AID CNCR2820390224 > 3.0.CO;2-R)

Newsome HH Jr, Brown PW, Terz JJ \& Lawrence W Jr 1978 Medical adrenalectomy and plasma steroids in advanced breast carcinoma. Surgery 83 83-89.

Osawa Y, Yoshida N, Fronckowiak M \& Kitawaki J 1987 Immunoaffinity purification of aromatase cytochrome P-450 from human placental microsomes, metabolic switching from aromatization to $1 \beta$ and $2 \beta$-monohydroxylation, and recognition of aromatase isozymes. Steroids 50 11-28. (doi:10.1016/0039-128X(83)90058-2)

Pasanen M \& Pelkonen O 1981 Solubilization and partial purification of human placental cytochromes P-450. Biochemical and Biophysical Research Communications 103 1310-1317. (doi:10.1016/0006291X(81)90265-5) 
Pedram A, Razandi M, Kim JK, O'Mahony F, Lee EY, Luderer U \& Levin ER 2009 Developmental phenotype of a membrane only oestrogen receptor $\alpha$ (MOER) mouse. Journal of Biological Chemistry 2843488 3495. (doi:10.1074/jbc.M806249200)

Pietras RJ \& Szego CM 1977 Specific binding sites for oestrogen at the outer surfaces of isolated endometrial cells. Nature 265 69-72. (doi:10.1038/ 265069a0)

Preston-Martin S, Pike MC, Ross RK, Jones PA \& Henderson BE 1990 Increased cell division as a cause of human cancer. Cancer Research $\mathbf{5 0}$ 7415-7421.

Preston-Martin S, Pike MC, Ross RK \& Henderson BE 1993 Epidemiologic evidence for the increased cell proliferation model of carcinogenesis. Environmental Health Perspectives 101 (Suppl 5) 137-138. (doi:10.1289/ ehp.93101s5137)

Razandi M, Pedram A, Jordan VC, Fuqua S \& Levin ER 2013 Tamoxifen regulates cell fate through mitochondrial oestrogen receptor $\beta$ in breast cancer. Oncogene 32 3274-3285. (doi:10.1038/onc.2012.335)

Robertson KM, O'Donnell L, Jones ME, Meachem SJ, Boon WC, Fisher CR, Graves KH, McLachlan RI \& Simpson ER 1999 Impairment of spermatogenesis in mice lacking a functional aromatase (cyp 19) gene. PNAS 96 7986-7991. (doi:10.1073/pnas.96.14.7986)

Rogan EG, Badawi AF, Devanesan PD, Meza JL, Edney JA, West WW, Higginbotham SM \& Cavalieri EL 2003 Relative imbalances in oestrogen metabolism and conjugation in breast tissue of women with carcinoma: potential biomarkers of susceptibility to cancer. Carcinogenesis 24 697-702. (doi:10.1093/carcin/bgg004)

Saeed M, Rogan E, Fernandez SV, Sheriff F, Russo J \& Cavalieri E 2007 Formation of depurinating N3Adenine and N7Guanine adducts by MCF-10F cells cultured in the presence of 4-hydroxyestradiol. International Journal of Cancer 120 1821-1824. (doi:10.1002/ijc.22399)

Sanchez AM, Flamini MI, Zullino S, Gopal S, Genazzani AR \& Simoncini T 2011 Estrogen receptor- $\{\alpha\}$ promotes endothelial cell motility through focal adhesion kinase. Molecular Human Reproduction 17 219-226. (doi:10.1093/molehr/gaq097)

Santen RJ 1981 Suppression of oestrogen with aminoglutethimide and hydrocortisone (medical adrenalectomy) as treatment of advanced breast carcinoma: a review. Breast Cancer Research and Treatment $\mathbf{1}$ 183-202. (doi:10.1007/BF01806259)

Santen RJ 2015 Vaginal administration of estradiol: effects of dose, preparation and timing on plasma oestradiol levels. Climacteric 18 121-134. (doi:10.3109/13697137.2014.947254)

Santen RJ, Lipton A \& Kendall J 1974 Successful medical adrenalectomy with amino-glutethimide. Role of altered drug metabolism. Journal of the American Medical Association 230 1661-1665. (doi:10.1001/jama. 1974.03240120029015)

Santen RJ, Santner S, Davis B, Veldhuis J, Samojlik E \& Ruby E $1978 a$ Aminoglutethimide inhibits extraglandular oestrogen production in postmenopausal women with breast carcinoma. Journal of Clinical Endocrinology and Metabolism 47 1257-1265. (doi:10.1210/ jcem-47-6-1257)

Santen RJ, Santner S, Davis B, Veldhuis J, Samojlik E \& Ruby E $1978 b$ Aminoglutethimide inhibits extraglandular oestrogen production in postmenopausal women with breast carcinoma. Journal of Clinical Endocrinology and Metabolism 47 1257-1265. (doi:10.1210/ jcem-47-6-1257)

Santen RJ, Worgul TJ, Samojlik E, Interrante A, Boucher AE, Lipton A, Harvey HA, White DS, Smart E, Cox C et al. 1981 A randomized trial comparing surgical adrenalectomy with aminoglutethimide plus hydrocortisone in women with advanced breast cancer. New England Journal of Medicine 305 545-551. (doi:10.1056/NEJM1981090 33051003)

Santen RJ, Worgul TJ, Lipton A, Harvey H, Boucher A, Samojlik E \& Wells SA 1982 Aminoglutethimide as treatment of postmenopausal women with advanced breast carcinoma. Annals of Internal Medicine 96 94-101. (doi:10.7326/0003-4819-96-1-94)
Santen RJ, Manni A, Harvey H \& Redmond C 1990 Endocrine treatment of breast cancer in women. Endocrine Reviews 11 221-265. (doi:10.1210/ edrv-11-2-221)

Santen RJ, Boyd NF, Chlebowski RT, Cummings S, Cuzick J, Dowsett M, Easton D, Forbes JF, Key T, Hankinson SE et al. 2007 Critical assessment of new risk factors for breast cancer: considerations for development of an improved risk prediction model. Endocrine-Related Cancer $\mathbf{1 4}$ 169-187. (doi:10.1677/ERC-06-0045)

Santen RJ, Allred DC, Ardoin SP, Archer DF, Boyd N, Braunstein GD, Burger HG, Colditz GA, Davis SR, Gambacciani M et al. 2010 Postmenopausal hormone therapy: an Endocrine Society scientific statement. Journal of Clinical Endocrinology and Metabolism 95 (7 Suppl 1) s1-s66. (doi:10.1210/jc.2009-2509)

Savage KI, Matchett KB, Barros EM, Cooper KM, Irwin GW, Gorski JJ, Orr KS, Vohhodina J, Kavanagh JN, Madden AF et al. 2014 BRCA1 deficiency exacerbates estrogen-induced DNA damage and genomic instability. Cancer Research 74 2773-2784. (doi:10.1158/0008-5472. CAN-13-2611)

Schultz-Norton JR, Ziegler YS \& Nardulli AM 2011 ER $\alpha$-associated protein networks. Trends in Endocrinology and Metabolism 22 124-129. (doi:10. 1016/j.tem.2010.11.005)

Selvaraj NG, Omi E, Gibori G \& Rao MC 2000 Janus kinase 2 (JAK2) regulates prolactin-mediated chloride transport in mouse mammary epithelial cells through tyrosine phosphorylation of $\mathrm{Na}^{+}-\mathrm{K}^{+}-2 \mathrm{Cl}^{-}$ cotransporter. Molecular Endocrinology 14 2054-2065.

Shozu M \& Simpson ER 1998 Aromatase expression of human osteoblast-like cells. Molecular and Cellular Endocrinology 139 117-129. (doi:10.1016/S0303-7207(98)00069-0)

Shozu M, Sumitani H, Segawa T, Yang HJ, Murakami K, Kasai T \& Inoue M 2002 Overexpression of aromatase P450 in leiomyoma tissue is driven primarily through promoter I.4 of the aromatase P450 gene (CYP19). Journal of Clinical Endocrinology and Metabolism 87 2540-2548. (doi:10.1210/jcem.87.6.8533)

Simpson ER \& Brown KA 2013 Minireview: Obesity and breast cancer: a tale of inflammation and dysregulated metabolism. Molecular Endocrinology 27 715-725. (doi:10.1210/me.2013-1011)

Song RX 2007 Membrane-initiated steroid signaling action of oestrogen and breast cancer. Seminars in Reproductive Medicine 25 187-197. (doi:10.1055/s-2007-973431)

Song RX, Mor G, Naftolin F, McPherson RA, Song J, Zhang Z, Yue W, Wang J \& Santen RJ 2001 Effect of long-term oestrogen deprivation on apoptotic responses of breast cancer cells to $17 \beta$-estradiol. Journal of the National Cancer Institute 93 1714-1723. (doi:10.1093/jnci/93.22.1714)

Song RX, Barnes CJ, Zhang Z, Bao Y, Kumar R \& Santen RJ 2004 The role of Shc and insulin-like growth factor 1 receptor in mediating the translocation of oestrogen receptor $\alpha$ to the plasma membrane. PNAS 101 2076-2081. (doi:10.1073/pnas.0308334100)

Song RX, Zhang Z, Chen Y, Bao Y \& Santen RJ 2007 Estrogen signaling via a linear pathway involving insulin-like growth factor I receptor, matrix metalloproteinases, and epidermal growth factor receptor to activate mitogen-activated protein kinase in MCF-7 breast cancer cells. Endocrinology 148 4091-4101. (doi:10.1210/en.2007-0240)

Steinach E \& Kun H 1936 Wien Klin Wachr 4916.

Steinach E \& Kun H 1937 Transformation of male sex hormones into a substance with the action of a female hormone. Lancet $\mathbf{1 3 3} 845$. (doi:10.1016/S0140-6736(00)88745-0)

Stuenkel CA, Davis SR, Gompel A, Lumsden MA, Hassan Murad M, Pinkerton JV \& Santen RJ 2015 Treatment of symptoms of the menopause: an Endocrine Society clinical practice guideline. Journal of Clinical Endocrinology \& Metabolism [in press]. (doi:10.1210/ jc.2015-2236)

Subbaramaiah K, Morris PG, Zhou XK, Morrow M, Du B, Giri D, Kopelovich L, Hudis CA \& Dannenberg AJ 2012 Increased levels of COX-2 and prostaglandin E2 contribute to elevated aromatase expression in inflamed breast tissue of obese women. Cancer Discovery 2 356-365. (doi:10.1158/2159-8290.CD-11-0241) 
Tanaka M, Telecky TM, Fukada S, Adachi S, Chen S \& Nagahama Y 1992 Cloning and sequence analysis of the cDNA encoding P-450 aromatase (P450arom) from a rainbow trout (Oncorhynchus mykiss) ovary; relationship between the amount of P450arom mRNA and the production of oestradiol-17 $\beta$ in the ovary. Journal of Molecular Endocrinology 8 53-61. (doi:10.1677/jme.0.0080053)

Terashima M, Toda K, Kawamoto T, Kuribayashi I, Ogawa Y, Maeda T \& Shizuta Y 1991 Isolation of a full-length cDNA encoding mouse aromatase P450. Archives of Biochemistry and Biophysics 285 231-237. (doi:10.1016/0003-9861(91)90354-L)

Thayer SA, Levin L \& Doisy EA 1931 Characterization of Theelol. Journal of Biological Chemistry 91 655-665.

Thompson EA Jr \& Siiteri PK 1974 Utilization of oxygen and reduced nicotinamide adenine dinucleotide phosphate by human placental microsomes during aromatization of androstenedione. Journal of Biological Chemistry 249 5364-5372.

Thompson EA Jr \& Siiteri PK 1979 Subcellular distribution of aromatase in human placenta and ovary. Hormone Research 11 179-185. (doi:10.1159/000179053)

Toda K \& Shizuta Y 1993 Molecular cloning of a cDNA showing alternative splicing of the $5^{\prime}$-untranslated sequence of mRNA for human aromatase P-450. European Journal of Biochemistry 213 383-389. (doi:10.1111/ j.1432-1033.1993.tb17772.x)

Toda K, Terashima M, Mitsuuchi Y, Yamasaki Y, Yokoyama Y, Nojima S, Ushiro H, Maeda T, Yamamoto Y \& Sagara Y 1989 Alternative usage of different poly(A) addition signals for two major species of mRNA encoding human aromatase P-450. FEBS Letters 247 371-376. (doi:10. 1016/0014-5793(89)81373-0)

Toda K, Terashima M, Kawamoto T, Sumimoto H, Yokoyama Y Kuribayashi I, Mitsuuchi Y, Maeda T, Yamamoto Y \& Sagara Y 1990 Structural and functional characterization of human aromatase P-450 gene. European Journal of Biochemistry 193 559-565. (doi:10.1111/ j.1432-1033.1990.tb19372.x

Townsley JD \& Brodie HJ 1968 Studies on the mechanism of oestrogen biosynthesis. 3. The stereochemistry of aromatization of C19 and C18 steroids. Biochemistry 7 33-40. (doi:10.1021/bi00841a005)

Tsai SA, Stefanick ML \& Stafford RS 2011 Trends in menopausal hormone therapy use of US office-based physicians, 2000-2009. Menopause 18 385-392. (doi:10.1097/gme.0b013e3181f43404)

Veler CD, Thayer S \& Doisy EA 1930 The preparation of the crystalline follicular ovarian hormone: theelin. Journal of Biological Chemistry $\mathbf{8 7}$ 357-371. (available at: http://www.jbc.org/content/87/2/357.citation)
Watkins ED 2007 In The Estrogen Elixer: A History of Hormone Replacement in America. Baltimore, MD, USA: The Johns Hopkins Press.

Watters JJ, Chun TY, Kim YN, Bertics PJ \& Gorski J 2000 Estrogen modulation of prolactin gene expression requires an intact mitogenactivated protein kinase signal transduction pathway in cultured rat pituitary cells. Molecular Endocrinology 14 1872-1881. (doi:10.1210/ mend.14.11.0551)

Welboren WJ, Sweep FC, Span PN \& Stunnenberg HG 2009 Genomic actions of oestrogen receptor $\alpha$ : what are the targets and how are they regulated? Endocrine-Related Cancer 16 1073-1089. (doi:10.1677/ERC09-0086)

Williams PA, Cosme J, Sridhar V, Johnson EF \& McRee DE 2000 Mammalian microsomal cytochrome P450 monooxygenase: structural adaptations for membrane binding and functional diversity. Molecular Cell 5 121-131. (doi:10.1016/S1097-2765(00)80408-6)

Wilson RA 1968 Feminine forever. New York, NY, USA: M Evans and Company.

Wu Q, Chambliss K, Umetani M, Mineo C \& Shaul PW 2011 Non-nuclear oestrogen receptor signaling in the endothelium. Journal of Biological Chemistry 286 14737-14743. (doi:10.1074/jbc.R110.191791)

Yager JD 2012 Mechanisms relating oestrogen to breast cancer. Translational Endocrinology \& Metabolism 3 75-93.

Yager JD \& Chen JQ 2007 Mitochondrial oestrogen receptors - new insights into specific functions. Trends in Endocrinology and Metabolism 18 89-91. (doi:10.1016/j.tem.2007.02.006)

Yager JD \& Davidson NE 2006 Estrogen carcinogenesis in breast cancer. New England Journal of Medicine 354 270-282. (doi:10.1056/ NEJMra050776)

Yang SH, Liu R, Perez EJ, Wen Y, Stevens SM Jr, Valencia T, BrunZinkernagel AM, Prokai L, Will Y, Dykens J et al. 2004 Mitochondrial localization of oestrogen receptor $\beta$. PNAS 101 4130-4135. (doi:10. 1073/pnas.0306948101)

Yoshimoto FK \& Guengerich FP 2014 Mechanism of the third oxidative step in the conversion of androgens to oestrogen by cytochrome P450 19A1 steroid aromatase. Journal of the American Chemical Society 136 15016-15025. (doi:10.1021/ja508185d)

Yue W, Wang JP, Li Y, Fan P, Liu G, Zhang N, Conaway M, Wang H, Korach KS, Bocchinfuso W et al. 2010 Effects of oestrogen on breast cancer development: role of oestrogen receptor independent mechanisms. International Journal of Cancer 127 1748-1757. (doi:10.1002/ ijc.25207)

Zondek B 1934 Oetrogenic hormone in the urine of the stallion. Nature $\mathbf{1 3 3}$ 494. (doi:10.1038/133494a0)

Received in final form 24 September 2015

Accepted 5 October 2015

Accepted Preprint published online 5 October 2015 http://jme.endocrinology-journals.org

DOI: 10.1530/JME-15-0128
(C) 2015 Society for Endocrinology Printed in Great Britain
Published by Bioscientifica Ltd 